\title{
Tax Noncompliance and Insider Trading
}

\author{
Juha-Pekka KALLUNKI* \\ University of Oulu, Stockholm School of Economics and Aalto University School of Business, \\ Contact Address: University of Oulu, P.O. Box 4600, FIN-90014 University of Oulu, Finland \\ Juha-Pekka.Kallunki@oulu.fi
}

Jenni MIKKONEN

University of Oulu, Department of Accounting P.O. Box 4600, FIN-90014 University of Oulu, Finland

Jenni.Mikkonen@oulu.fi

\author{
Henrik NILSSON \\ Stockholm School of Economics, Department of Accounting \\ P.O. Box 6501, SE-113 83 Stockholm, Sweden \\ Henrik.Nilsson@hhs.se \\ Hanna SETTERBERG \\ Stockholm School of Economics, Department of Accounting \\ P.O. Box 6501, SE-11383 Stockholm, Sweden \\ Hanna.Setterberg@hhs.se
}

First Version: January 8, 2014

Final Version: November 26, 2015

*Corresponding author 


\title{
Tax Noncompliance and Insider Trading
}

\begin{abstract}
This paper explores whether insiders who have shown noncompliance with the tax law ('noncompliant insiders') are more prone to exploit their information advantage in insider trading, compared to other insiders ('compliant insiders'). Our empirical results from analyzing archival data of all insider trades in Sweden show that noncompliant insiders use more of their information advantage to trade their insider stocks shortly before significant stock price changes, compared to compliant insiders. These results remain similar after controlling for various insider- and firm-specific determinants of insider returns, including firm and year fixed effects. We believe our results are of interest for academics and regulatory authorities monitoring and screening insider trading activity.
\end{abstract}

JEL Classification: M41, G10, G30, K42

Keywords: Insider trading, Tax noncompliance 


\section{Introduction}

"Honest trading, and equal access to material information. It's simply a question of integrity... It's a question of right and wrong." (Chairman Arthur Levitt, U.S. Securities and Exchange Commission, February, 1998)

Corporate insiders routinely have access to valuable information about firm prospects, which gives them a superior information advantage over other investors in the stock market. ${ }^{1}$ Regulatory authorities, firms as insiders' employers, and the general public monitor insiders' trading on the stocks of their firm. In particular, insider trading is restricted by legislation, by comply-or-explain-based corporate governance codes, by company policies and procedures, and by the reputational and political costs that may arise if trading is regarded as questionable by the employer or public media. Hence, it is the combined threats of regulatory scrutiny, litigation, and adverse publicity that limit insiders' desire to use their information advantage when trading the stocks of their firm (e.g. Huddart et al., 2007).

In this paper, we investigate whether insiders who have been charged with administrative penalties by the tax authorities due to noncompliance with the tax law (hereafter 'noncompliant insiders') are more prone to exploit their information advantage in insider trading, compared to other insiders (hereafter 'compliant insiders'). With few published exceptions, insider trading research assumes that insiders are homogenous in their personal traits, although we know that people are different. Insider trading decisions are made individually by insiders, who need to balance their desire to gain from insider transactions on one hand, with legal, political, and

\footnotetext{
${ }^{1}$ Insiders are employees of a firm who hold specific information that is likely to affect the stock price of the firm. Following the literature, we examine insider trading that is disclosed to the regulatory authority. In Sweden, this regulatory authority is the Finansinspektionen (the Swedish Financial Supervisory Authority), and in the United States it is the U.S. Securities and Exchange Commission (SEC). Since insiders may be reluctant to report trades that could be easily interpreted as being based on the use of material private information by the regulator, it follows that we do not directly address the issue of illegal insider trading.
} 
reputational costs due to trading restrictions on the other hand. Insider trading shortly before significant stock price changes is considered to be unacceptable and unethical behavior by corporate insiders. Hence, insiders' ethical beliefs and their attitudes towards what is regarded as unacceptable and unethical behavior are likely to play an important role in their willingness to exploit their information advantage in insider trading. Extensive literature on tax noncompliance moreover shows that individuals' personal traits affect their tax compliance behavior. In particular, individuals who decide not to comply with the tax law are prone to ethical misconduct, and to make personal gains at the expense of others (e.g. Reckers et al., 1994; Ghosh and Crain, 1996; Kaplan et al., 1997; Henderson and Kaplan, 2005). Therefore, we hypothesize that, by being prone to commit ethical misconduct to achieve personal gains, insiders who have shown noncompliance with the lax law are more prone to use their information advantage to earn also insider gains, compared to compliant insiders. ${ }^{2}$

We contribute to the insider trading literature by analyzing large archival data to explore whether insiders with adverse personal traits exploit their information advantage when trading insider stocks. While numerous prior studies have linked the gains from insider trading to the characteristics of the firm (e.g. Lakonishok and Lee, 2001; Aboody et al., 2005), only a few studies examine whether insiders' personal characteristics are related to their willingness to exploit insider information (Davidson et al., 2014; Skaife et al., 2013; and Hillier et al., 2015). For instance, Hillier et al. (2015) find that insider fixed effects explain up to a third of the variability of insider returns and have up to three times more explanatory power than firm fixed

\footnotetext{
${ }^{2}$ Noncompliance with the tax law refers to the administrative penalties (i.e. failure-to-file and surcharge penalties) assessed by the Skatteverket (the Swedish Tax Agency) due to violations of the Taxation Act (1990:324). These penalties reflect careless behavior by the taxpayer, as described in Section 3.1.2. The Skatteverket is the corresponding governmental tax agency to the Internal Revenue Service (IRS) in the U.S. The terms "failure-to-file penalty" and "surcharge penalty" in this study refer to the terms "delay penalties" and "tax surcharges" used in the official documents by the Skatteverket.
} 
effects. They also find some evidence that insider returns are related to the insider's gender and education. Despite these insights, the question of what are the insider fixed effects that drive the observed variation in insiders' trading behavior is still largely open. We contribute to this line of research in three main ways.

First, we focus on an insider's tax noncompliance behavior, which is a widely studied and accepted measure of an individual's personal attitude towards ethical misconduct. Many studies suggest that most taxpayers are inherently honest and therefore choose to comply with tax laws, regardless of their financial incentives to cheat (Alexander and Feinstein, 1987; Shefrin and Triest, 1992). Hence, a taxpayer's decision not to comply with the tax law is an indication of her personal attitude towards ethical misconduct in achieving personal gains at the expense of others, both in general and those specific to tax reporting. ${ }^{3}$ The strong effect of threats of guilty feelings, coupled with the relatively low sense of moral obligation to comply with tax laws is a major driver of tax evasion behavior (Grasmick and Scott, 1982). Moreover, an individual's decision not to comply with the tax law captures different aspects of her personal traits than, for example, criminal records or measures of over-confidence used in previous insider trading studies. For instance, Grasmick and Scott (1982) find that the deterrent effect of an individual's guilty feelings about tax evasion is greater than that of the informal or legal sanctions. Hence, we expand recent studies on insider's trading behavior (e.g. Davidson et al., 2014; Skaife et al., 2013; and Hillier et al., 2015) by focusing on tax noncompliance, which is a direct measure of an insider's personal attitude towards ethical misconduct in achieving personal gains at the expense of others.

\footnotetext{
${ }^{3}$ If an insider exploits her private information to sell (buy) insider stocks before stock price declines (increases), she receives personal gains at the expense of uninformed investors who buy or fail to sell (sell or fail to buy) on the basis of that information.
} 
Second, previous studies examining insiders' personal traits typically analyze hand-collected data sets for a small group of predefined insiders, such as those of fraud firms, whereas we use archival data for all insiders of all listed firms in a given country. ${ }^{4}$ Our comprehensive archival data enables us to assess whether the previous results on the effect of insiders' personal traits on their trading behavior are sample-specific or, alternatively, whether they can be generalized to the whole population of insiders and firms. It is likely that insiders in, for example, fraud firms behave differently from insiders in other firms. Third, our rich data enables us to control in our analyses for the previously found motives of insider trading, including insiders' portfolio rebalancing and liquidity needs and their legal records, to isolate the incremental role of tax noncompliance.

Finally, we contribute to the tax noncompliance literature by exploring corporate executives' tax noncompliance behavior. While the tax noncompliance literature has focused on examining ethical misconduct as a determinant of taxpayers' tax noncompliance behavior, little is known about whether such behavior is reflected in adverse behavior by corporate executives. One exception is Chyz (2013), who shows that executives who appear to evade personal taxes are associated with tax sheltering at the firm level. To the best of our knowledge, our paper is the first one to explore whether executives' prior noncompliance with tax laws is related to the extent to which they exploit their information advantage for personal gain in insider trading.

In our empirical analyses, we utilize a large archival data set on 3,392 corporate insiders from all Swedish listed firms, and 14,706 insider transactions by these insiders over the period from 2000 to 2008. We find that a non-trivial proportion (4.2\%) of insiders have violated the tax law (Taxation Act 1990:324) in the year preceding their insider trades, and consequently, have

\footnotetext{
${ }^{4}$ For instance, the sample in Davidson et al. (2014) consists of 236 firms involved in fraud, financial reporting errors, and bankruptcy, and 558 randomly selected non-fraud firms.
} 
been charged with an penalty by the Swedish Tax Agency (Skatteverket), with the average penalty being 54 and the maximum 3,828 (thousands of Swedish Crowns). ${ }^{5}$ Consistent with our hypothesis, we find that these noncompliant insiders earn both statistically and economically greater insider returns, compared to compliant insiders. In particular, the mean (median) onemonth market-adjusted stock return after noncompliant insiders' sales is $-3.3 \%(-2.8 \%)$, which is $3.3 \%(1.9 \%)$ units lower than the mean (median) return for compliant insiders. Accordingly, the mean (median) one-month market-adjusted stock return after noncompliant insiders' purchases is $6.3 \%(3.1 \%)$, which is $4.3 \%(2.2 \%)$ units greater than the mean (median) return for compliant insiders. These results remain after controlling for various likely insider- and firmspecific determinants of insider returns, including insiders' liquidity needs, portfolio rebalancing objectives, capital gain taxation considerations, and firm and year fixed effects.

As for policy implications, we believe that our results are of interest for regulatory authorities and policy-makers. In particular, identifying insiders' personal traits related to the exploitation of insider information should be of interest to regulatory authorities who design monitoring mechanisms for insider trading. Tax sanctions imposed by the tax authority are public information in Sweden, which naturally helps to identify noncompliant insiders. Although this information is not readily available to the general public in many other countries, our results imply that the regulatory authorities monitoring insider trading may benefit from sharing information with the tax authorities.

The remainder of the paper is divided into four sections. In Section 2, we review the related literature. Section 3 describes the data and introduces the methodology applied in this study. Section 4 reports and discusses the results of the analyses. Finally, we provide concluding remarks in Section 5.

\footnotetext{
${ }^{5} 1$ SEK is equal to 0.12 USD.
} 


\section{Literature and hypothesis development}

\subsection{Insiders' trading behavior}

Economic models of informed trading describe insiders' trading behavior as being driven by their desire to maximize financial gains from their superior information about future firm prospects (Kyle, 1985). In practice, insider trading restrictions limit insiders' desire to exploit their information advantage. In virtually all countries, insider trading is regulated by legislation, and consequently, monitored by regulatory authorities (e.g. Bhattacharya and Daouk, 2002; Brockman et al., 2014). Comply-or-explain-based corporate governance codes often complement insider legislation. Insiders' desire to exploit their superior information is also limited by their obligation to report all insider stock trades to a regulatory authority, which continually looks for signs of illicit trading behavior. The regulatory authority also discloses insider trades to the general public, which creates strong disincentives for insiders to trade on their superior information, as outside investors and the business press screen insiders' stock trades on a regular basis for signals about future firm prospects, and for signs of opportunistic behavior (e.g. Brochet, 2010; Badertscher et al., 2011). Hence, insider trades perceived to be opportunistic are likely to receive adverse investor and media attention, thereby increasing the probability of regulatory scrutiny, as well. ${ }^{6}$

Finally, insider trading is also restricted by the firms themselves. Prior research suggests that firms take an active role in restricting their employees' trading on the stocks of the firm, because

\footnotetext{
${ }^{6}$ To screen for possible violations of insider trading legislation, regulatory agencies such as the SEC use information from various sources, including investor tips and complaints, other securities industry sources, and media reports (SEC, 2013). The business press moreover publicizes certain insider trades, and it is plausible that insider sales before significant stock price declines and insider purchases before large price increases attract more media attention.
} 
firms face reputational and political costs in the case of questionable and especially illegal insider trading. In the U.S., the Insider Trading and Securities Fraud Enforcement Act of 1988 (ITSFEA) made firms partially liable for any employee's illegal insider trading (Garfinkel, 1997). To minimize these costs, firms adopt internal policies and procedures such as specific black-out periods (Bettis et al., 2000; Lee et al., 2014) and preapproval of employees' stock trades (Jagolinzer et al., 2011). All insiders have an individual responsibility to comply with company-level trading restrictions.

Despite the various restrictions and the monitoring of insider trading, a common finding in the literature is that insiders are able to use their information advantage to earn insider trading gains (e.g. Seyhun, 1986; Huddart and Ke, 2007). A great deal of research effort has been devoted to examining insiders' trading behavior aggregated at the firm level. These studies have linked the cross-sectional variation in insider trading gains to firm characteristics such as firm size (Lakonishok and Lee, 2001), book-to-market ratio (Rozeff and Zaman, 1998), stock repurchases (Bonaime and Ryngaert, 2010), management earnings forecasts (Kraft et al., 2014), good vs. bad earnings news (Hillier and Marshall, 2002), the quality of earnings (Aboody et al., 2005; Xiao, 2015), and the effectiveness of internal control systems (Skaife et al., 2013).

By contrast, the empirical evidence on the likely heterogeneity among individual insiders in their trading behavior is surprisingly limited. Although some insider trading is obviously due to liquidity and diversification reasons (Jin and Kothari, 2008; Kallunki et al. 2009), a significant portion of it is explained by the exploitation of insider information (e.g. Huddart and Ke, 2007; Hillier et al., 2015). Besides demographic factors such as gender, birth cohort, and education (Inci et al., 2014; Hillier et al., 2015) very little is known about how insiders' personal traits affect their trading behavior. Hillier et al. (2015) find that insiders systematically vary in their 
willingness to use their superior information in insider trading, given the regulatory and reputational risks. However, the question of what are the specific factors that drive the observed variation in individual insiders' trading behavior is still largely open.

It has been suggested in the experimental accounting literature that informed insider trading is widely perceived as an unethical conduct (Kaplan et al., 2009), especially selling ahead of stock price declines (Moore, 1990; Beams et al., 2003). Given that insiders make their trading decisions individually, those insiders who are characterized by low personal ethics or integrity are prone to take advantage of their insider information, especially in their selling decisions. The limited empirical evidence on testing these predictions is mixed. For instance, Bhattacharya and Marshall (2012) discuss, but do not test, whether insiders' psychological motives affect their decisions to commit illegal insider trading. Skaife et al. (2013) and Davidson et al. (2014) examine whether insiders who lack a respect for rules and policies, or who demonstrate poor ethical behavior, are more likely to buy and sell on their private information, but their results are contradictory. Specifically, Skaife et al. (2013) find that the extent of informed insider selling in firms with material internal control system weaknesses is related to weak 'tone at the top', suggesting that the top management's lack of integrity is associated with profitable insider selling in firms where the existing controls are weak. In contrast, Davidson et al. (2014) find that executives with legal records, and those with highly materialistic tendencies, have a higher propensity to use inside information in their insider purchase trades, but not in their sale trades. ${ }^{7}$ They attribute this trading asymmetry to the higher legal risk involved in insider selling as described by Cheng and Lo (2006).

\footnotetext{
${ }^{7}$ Davidson et al. (2014) purchase background checks for the executives in a sample of public U.S. firms. Due to the high costs of collecting data, their sample is not entirely randomly selected, and this might limit the generalizability of their results to the general population of the public U.S. companies.
} 
To summarize, stock market transactions made by corporate insiders are scrutinized by regulators, investors, public media, and insiders' employers, who also screen these transactions on a regular basis. Therefore, insiders face not only direct legal costs resulting from illegal insider trading, but also various forms of reputational and political costs resulting from questionable insider trading. What is regarded as questionable insider trading is a matter of judgment, which gives insiders a considerable amount of personal discretion in their trading. Insiders with adverse personal traits are likely to take advantage of this discretion for personal gain when trading the stocks of their insider firm.

\subsection{Taxpayers' noncompliance behavior}

Economic models of tax compliance have traditionally assumed that taxpayers' noncompliance behavior is primarily influenced by their financial incentives to cheat and by the threat of detection and penalties for detected noncompliance (Allingham and Sandmo, 1972; Srinivasan, 1973). While these models assume that taxpayers show a similar willingness to evade taxes based on their economic reasoning, many studies in both economics and sociology literature on tax compliance have questioned such an assumption (e.g. Graetz et al., 1986; Alm et al., 1992; and Erard and Feinstein, 1994). For instance, both empirical and analytical studies suggest that most taxpayers are inherently honest and therefore choose to comply with the tax law, regardless of their financial incentives to cheat (Alexander and Feinstein, 1987; Shefrin and Triest, 1992). Interestingly, several studies on taxpayer behavior show that taxpayers' personal characteristics, including their attitudes towards what is regarded as acceptable and unacceptable behavior, affect their decisions on whether or not to comply with tax laws (e.g. Reckers et al., 1994). 
Since the pioneering work by Schwartz and Orleans (1967), a broad literature on the role of ethics in tax compliance has provided consistent evidence that taxpayers' decisions to comply with tax laws are influenced by their ethical beliefs, both in general and those specific to tax reporting (e.g. Collins et al., 1992; Reckers et al., 1994; Hanno and Violette, 1996; Bobek and Hatfield, 2003; Henderson and Kaplan, 2005). Specifically, general ethical beliefs reflect individuals' collective attitudes toward right and wrong, and are not specific about a particular behavior or decision (Henderson and Kaplan, 2005). Kaplan et al. (1997) find that individuals who apply low moral reasoning in their decision-making have significantly higher intentions to avoid taxes. ${ }^{8}$ Ghosh and Crain (1996) moreover show that individuals who are willing to achieve personal gains at the expense of others are less likely to comply with tax laws.

Another interesting finding in the tax noncompliance research is that individuals distinguish tax noncompliance from criminal activities. In particular, people tend to perceive tax noncompliance more as a violation than a crime (Vogel, 1974; Song and Yarbrough, 1978; Burton et al., 2005). Song and Yarbrough (1978) report that taxpayers regard tax evasion as only slightly more serious than stealing a bicycle, yet less serious than drunk driving or car theft. Previous studies also show that individuals' ethical standards do not predict crimes such as theft and drunk driving in the same way they predict tax evasion (Grasmick and Scott, 1982; Grasmick and Bursick, 1990). For instance, Grasmick and Scott (1982) find that the strong effect of threats of guilt feelings, coupled with the relatively low sense of moral obligation to comply with tax laws is a major driver of tax evasion behavior. They moreover find that the inhibitory

\footnotetext{
${ }^{8}$ A person who utilizes low moral reasoning when making decisions, such as whether or not to trade on insider information, focuses mainly on oneself, not considering whether a particular behavior is right or wrong, and whether the personal benefits are achieved at the expense of others (Kaplan et al., 1997). The model of moral reasoning was originally developed by Kohlberg (1969), and it has been widely applied in empirical research to examine individual behaviors in different contexts, including criminology and business environments.
} 
effect of the guilt feelings associated with tax evasion is greater than that of informal or legal sanctions.

Taken together, an individual's tax noncompliance behavior indicates lower personal ethics in general, along with a higher willingness to achieve personal gains at the expense of others. Moreover, tax noncompliance behavior is likely to capture different aspects of personal traits than criminal behavior.

\subsection{Hypothesis}

The literature discussed above shows that insiders' desire to exploit their superior information about firm prospects in insider trading is restricted not only by direct legislation, but also by potential reputational and political costs that insiders and their firms face due to public disclosure of insider trades. Consequently, insiders need to assess whether their stock market transactions can be perceived as questionable by outside investors, by the business press, or by their employee, or even illegal by the regulatory authority. What is considered questionable insider trading is largely a matter of personal judgment, which gives insiders a substantial amount of discretion in their trading. Previous literature shows that insiders' personal traits play a role in their trading behavior, and that insiders differ in their willingness to use their information advantage in insider trading. Extensive literature on tax compliance reports that individuals who decide not to comply with tax laws are more prone to ethical misconduct, and to make personal gains at the expense of others. Consequently, given the opportunity, insiders who have shown noncompliance with the tax law are more likely to take advantage of their insider information when trading the stocks of their firm, compared to other insiders. 
A possible counterargument for this reasoning is that the various forms of insider trading restrictions and monitoring should constrain insiders' individual behavior (e.g. Garfinkel, 1997; Agrawal and Nasser, 2012). In other words, insiders with adverse personal traits should not be able to make greater returns from their insider transactions. To mitigate the legal risk, reputational damage and other political costs due to negative publicity that may arise if employees trade on their insider stocks before significant changes in the stock price, firms often adopt stringent policies and procedures for insider trading. In essence, whether or not insiders with adverse personal traits are able to use insider information in insider trading depends on how effective these insider trading restrictions and monitoring mechanisms are. We nevertheless form our hypothesis in the alternate form:

H1: Insiders who have shown noncompliance with the tax law are more prone to exploit their information advantage in insider trading, compared to other insiders.

\section{Data and methodology}

\subsection{Data sources}

We utilize comprehensive archival data on Swedish insiders obtained from various nationwide official databases maintained by Swedish tax, regulatory, and police authorities. All the data is in electronic form, and we use investors' unique personal identity numbers (social security codes) to match different databases. Our sample period is from January 2000 to December 2008. In the final data set, there are 394 unique firms, 3,392 unique insiders, and 14,706 insider transactions consisting of 5,610 sale transactions and 9,096 purchase transactions. 
We also estimate our multivariate regressions by excluding from the final data set insider trades made by those noncompliant insiders who have been convicted or suspected of crimes.

\subsubsection{Insider trading data}

We obtain daily insider transactions data, comprising all the details of each insider's transactions (the insider's name and social security code, the name of the firm traded, the number of shares traded, and the day on which the transaction was made) from the Finansinspektionen. Following earlier studies on insider trading (Ke et al., 2003; and Kallunki et al., 2009), we include in our analyses all open market purchases and sales by corporate insiders. Accordingly, non-open market transactions, such as option exercises, transactions related to bonuses, pensions, and other benefit program transactions, and gifts, are not regarded as insider trades. ${ }^{9}$ In the case of multiple insider trades on the same day for a given insider, we net all these trades.

In Sweden, insider trading regulation is in accordance with European Union Directives on the Regulation of Insider Trading (EEC Directive 89/592) and on Insider Dealing and Market Manipulation (Directive 2003/6/EC). Hence, the Swedish insider legislation is of high quality and very similar to that in the U.S. (e.g. Beny, 2005). The main difference is that, while illegal insider trading is both a criminal and a civil offense in the U.S., it is only a criminal offense in Sweden. This means that the Finansinspektionen does not have a civil enforcement authority in illegal insider trading like the SEC. In addition, the maximum penalty for insider trading crimes in Sweden is four years of imprisonment, compared to the maximum of ten years in the U.S.

In addition to statutory legislation, country-specific differences in corporate cultures and the level of corporate governance may affect how acceptable trading on insider information is

\footnotetext{
${ }^{9}$ Following previous insider trading studies, we also exclude very small trades (size of trade $<10,000$ SEK) from our analyses. 1 SEK is equal to 0.12 USD.
} 
perceived in corporate practice (Bris, 2005). Denis and $\mathrm{Xu}$ (2013) report that Swedish executives, like their US counterparts, largely agree that insider trade is not common in the stock market. In terms of the level of corporate governance, Aggarwal et al. (2009) find that Sweden places among the top ten countries, not far from the U.S. In summary, insider trading legislation, its enforcement, corporate cultures and the level of corporate governance are similar in Sweden and in the U.S. Appendix 1 briefly describes the details of the Swedish insider legislation, along with the key milestones in its development.

\subsubsection{Tax noncompliance data}

We obtain data on insiders' tax compliance from the Skatteverket (the Swedish Tax Agency), which is the corresponding governmental tax agency to the IRS in the U.S. This dataset contains information about the administrative penalties imposed by the Skatteverket when a taxpayer fails to comply with the Swedish tax law. In Sweden, two kinds of sanctions are applied to tax noncompliance: administrative penalties and the penalties of the criminal justice system. The administrative penalties include failure-to-file and surcharge penalties that are assessed by the tax agency (Taxation Act, 1990:324). Penalties of the criminal justice system, namely fines and imprisonments, are ordered by the courts (Tax Crime Act, 1971:69 2§). In our analyses, we focus on the administrative penalties, as they are much more common than tax-related criminal convictions. Administrative tax penalties are also public information in Sweden.

In Sweden, the process of filing an income tax return is as follows. ${ }^{10}$ In April each year, a taxpayer receives a tax return form on which all the data supplied by employers and financial institutions has been entered by the Skatteverket. After receiving the tax return form, the taxpayer

\footnotetext{
${ }^{10}$ The income tax return filing process is described here according to the Swedish Tax Agency (2010, 2011).
} 
is responsible for checking the figures and, when relevant information is missing, adding the missing information or claims for deductions. According to the Skatteverket, more than $40 \%$ of taxpayers change or add information to their pre-filled tax return form. Hence, the Skatteverket usually does not have all the information needed for taxation, unless self-reported by the taxpayer. The taxpayer must sign the form and return it to the Skatteverket by the annual tax filing deadline, that is, by the first working day of May. As of 2002, taxpayers may file their income tax return electronically, and in 2010, $60 \%$ of Swedish taxpayers filed their tax return this way. A survey conducted by the Skatteverket in 2006 showed that $60 \%$ of taxpayers regarded filing their tax return as easy.

By law, the Skatteverket may assess penalties on a taxpayer for failing to file a tax return by the tax-filing deadline, in accordance with the Taxation Act (1990:324) ${ }^{11}$ This failure-to-file penalty can be withdrawn if the taxpayer files the tax return shortly after receiving a reminder from the Skatteverket, and can show a reasonable cause for not filing on time. In addition, it is possible for the taxpayer to apply for an extension (10 days) of the tax-filing deadline in advance, and thereby avoid a failure-to-file penalty. This failure-to-file penalty usually amounts to SEK 1,000, but increases by an additional SEK 2,000 for filing more than five months late. According to official government statistics for the tax year 2010, only $0.7 \%$ of the annual income tax return filings were filed late and associated with a failure-to-file penalty. The fact that such a small proportion of all annual income tax returns are filed late is consistent with the notion that filing a tax return is easy in Sweden. It also indicates that late filing is not a common practice among taxpayers in Sweden.

\footnotetext{
${ }^{11}$ For the failure-to-file penalties, the relevant parts of the Swedish Taxation Act (1990:324) discussed in this paper are Chapter 5, $9 \S$ and $11 \S$.
} 
In addition to failure-to-file penalties, the Skatteverket may impose surcharge penalties in accordance with the Taxation Act (1990:324), when a taxpayer has filed incorrect information or failed to file a tax return at all. Specifically, information is deemed to be incorrect by the Skatteverket if it is clearly shown that either the information provided by the taxpayer is incorrect, or the information provided to guide taxation has been omitted. The normal surcharge penalty applied to income tax is $40 \%$ of the incorrectly reported tax amount. ${ }^{12}$ By law, the Skatteverket shall not apply surcharge penalties to incorrect but insignificant numbers, i.e. those below SEK 5,000. In addition, apparent mistakes by the taxpayer do not lead to surcharge penalties. The taxpayers can also avoid surcharge penalties by self-correcting previously incorrect tax report filings. In 2010, $2.6 \%$ of all income tax return filings included surcharge penalties.

Although there are some likely differences in taxpayers' noncompliance behavior between Sweden and the U.S., both anecdotal and empirical evidence suggest that these differences are minor. ${ }^{13}$ For instance, Tsakumis et al. (2007) find that both the U.S. and Sweden are among the countries with the lowest level of tax evasion. Accordingly, Alm and Torgler (2006) find that individuals in the U.S. have the highest tax morals, i.e. the intrinsic motivation to pay taxes, across all countries, and that Sweden ranks close at the fifth place. In summary, receiving a failure-to-file or surcharge penalty in Sweden is an indication of unethical and careless behavior by the taxpayer.

\footnotetext{
${ }^{12}$ This figure can be reduced to $10 \%$ if the withheld amount could be calculated from other numbers provided to the tax authority. Regarding surcharge penalties, the relevant parts of the Swedish Taxation

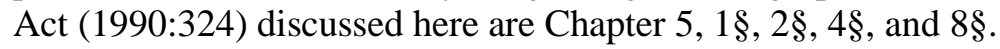

${ }^{13}$ For instance, the estimated net tax gap in Sweden in 2007 was $10.9 \%$ (SEK 133 billion) of the estimated total tax liability (Swedish Tax Agency, 2010), while in U.S. the corresponding percentage figure for 2006 was $14.5 \%$ ( $\$ 385$ billion; Internal Revenue Service, 2012).
} 


\subsubsection{Stock holdings, criminal convictions, market and accounting data}

Regarding other person-related data, data on insider stockholdings is obtained from the NCSD (the Nordic Central Securities Depository Group). Data on insiders' criminal convictions comes from the Brå (the Swedish National Council for Crime Prevention). The data includes information on individuals who have been found guilty by a court of law or received summary punishments by prosecutors since 1974. The dataset does not include minor offenses such as speeding, parking, and violations of local bylaws for which the punishment is an on-the-spot fine. Because it is likely that serious crimes are underrepresented in the data on actual convictions (Korsell, 2001), we also include data on individuals who have been under investigation for serious crimes to reduce the selection bias from focusing only on individuals that are actually convicted. The data on suspected criminal actions by corporate insiders is obtained from the Swedish National Police Board, comprising a record of all Swedish citizens who have been under investigation for serious crimes since 1991. In this data set, suspicion of a crime means that a police investigation had been launched but the prosecutor eventually decided not to pursue the case in court.

Finally, we retrieve the daily stock prices and annual accounting data from the Thomson Datastream. Appendix 2 summarizes our data sources and variables.

\subsection{Preliminary data analysis}

Table 1 provides summary statistics on the 3,392 Swedish insiders in our sample. Statistics reported in Panel A of Table 1 show that the majority of the insiders in our sample are male and middle-aged. Panel B of Table 1 further shows that approximately $10 \%$ of the insiders are CEOs, $32 \%$ are board members, and the remaining 58\% hold other insider positions. Panel C of Table 1 
reports statistics on how actively insiders trade their insider stocks. The average insider executed 3.19 sale and 3.53 purchase transactions over the sample period of nine years. However, while some insiders have made only a few trades, others have traded their insider stocks very actively. Consistent with prior studies (e.g. Lakonishok and Lee, 2001), we find that the values of insiders' sale transactions exceeds that of purchases. In particular, the average value of a sale transaction (SEK 5,128,000) is almost twice the value of a purchase transaction (SEK $2,933,000)$.

(Insert Table 1 about here)

Table 2 reports summary statistics on tax noncompliance for insiders in our sample. Panel A of Table 2 shows that out of all 3,392 insiders in our sample, 142 (4.2\%) did not comply with the Taxation Act (1990:324) in the year preceding their insider trades, and consequently received administrative penalties (a failure-to-file penalty or/and surcharge penalty) from the Skatteverket. The proportion of insiders who have been charged with administrative penalties from the Skatteverket is similar to that of the entire Swedish population, as discussed earlier in Section 3.1.2. Out of the 142 insiders who have received administrative tax penalties, $43(30.3 \%)$ have been charged with surcharge penalties, 112 (78.9\%) have been charged with failure-to-file penalties, and $13(9.2 \%)$ have been charged with both surcharge penalties and failure-to-file penalties.

Panel B of Table 2 reports descriptive statistics on the size of administrative penalties charged to the insiders by the Skatteverket. We report these statistics for the total size of the penalties, aggregating both the surcharge penalty and the failure-to-file penalty if an insider has 
been charged with both. We also report the same statistics for surcharge penalties and failure-tofile penalties separately. The statistics for the total size of the penalties $(\mathrm{N}=179)$ reveal considerable variation, as the size of the penalties ranges from a minimum of 500 SEK to a maximum of 3,828,534 SEK. Regarding the two different types of penalties, the surcharge penalties are the largest penalties, while the failure-to-file penalties are considerably smaller. Taken together, although both surcharge penalties and failure-to-file penalties have been charged due to violations of the Taxation Act (1990:324), the size of penalties varies. Finally, to allow for the possibility that penalties of a larger size indicate more severe misconduct, we use a continuous tax noncompliance variable in our empirical analyses. ${ }^{14}$

(Insert Table 2 about here)

\subsection{Model specifications}

To examine whether insiders who have shown noncompliance with the tax law are more prone to use their information advantage when trading the stocks of their firms, we estimate multivariate regressions in which the abnormal stock return following insider trades is the dependent variable. We include in each regression a set of insider- and firm-specific control variables as well as firm and year fixed effects. Specifically, we estimate the following Model (1) from our insider transactions data separately for insider sales and purchases:

BHAR $_{j t}=\alpha_{0}+\beta_{1} T A X_{i t}+\beta_{2} C R I M E_{i}+\beta_{3} A G E_{i}+\beta_{4} G E N D E R_{i}+\beta_{5} T E N U R E_{i j t}+\beta_{6} C E O_{i j t}$

\footnotetext{
${ }^{14}$ We have also re-estimated all our regressions by using a dummy variable that takes a value of one if an insider $i$ has received an administrative penalty (a surcharge penalty or/and a failure-to-file penalty) from the Skatteverket due to noncompliance with the tax law during the fiscal year prior to day $t$, and otherwise zero. These results are similar to those based on the continuous variable.
} 


$$
\begin{aligned}
& +\beta_{7} \text { BOARDMEM }_{i j t}+\beta_{8} \text { TRADEVAL }_{i j t}+\beta_{9} \text { VALUEDIV }_{i j t}+\beta_{10} \text { LIQUIDITY }_{i t} \\
& +\beta_{11} \text { DECLOSS }_{j t}+\beta_{12} \text { NUMINS }_{i t}+\beta_{13} \text { MOMENTUM }_{j t}+\beta_{14} \text { ROA }_{j t}+{ }_{15} L N M V_{j t} \\
& +\beta_{16} \text { PB }_{j t}+\sum_{k=1}^{394} \varphi_{\mathrm{k}} \text { FIRM }_{k_{j}}+\sum_{y=2000}^{2007} \gamma_{y} \text { YEAR }_{y}+\varepsilon_{i j t}
\end{aligned}
$$

where $i$ denotes insider, $j$ denotes firm, and $t$ denotes day. The observations are individual insiders' trades. The dependent and independent variables in Model (1) are as described below in Sections 3.4.1., 3.4.2. and in Appendix 2.

\subsection{Variable measurement}

\subsubsection{Dependent variables}

The dependent variable is the buy-and-hold abnormal (market-adjusted) stock return over a one-month period following an insider's purchase or sale trade that takes place on day $t$ for firm $j$ (the variable $B H A R_{j t}$ ). A higher (lower) abnormal stock return following an insider's purchase (sale) transaction indicates the exploitation of the information advantage by the insider who made the trade. We use abnormal returns measured over a one-month period, because previous studies suggest that insider trading shortly before significant stock price movements involves higher legal and reputation-related risk both for the insider and her firm (e.g. Ke et al., 2003; Huddart et al., 2007).

\subsubsection{Independent variables}

\subsubsection{Tax noncompliance behavior}

To measure insiders' tax noncompliance behavior, we construct the variable $T A X_{i t}$ from our data on the administrative penalties imposed on insiders by the Skatteverket because of the 
violations of tax laws. Specifically, the variable $T A X_{i t}$ equals the SEK value of the total administrative penalty (the sum of a failure-to-file penalty and surcharge penalty) imposed on insider $i$ due to her noncompliance with the Taxation Act (1990:324) in the fiscal year preceding day $t$, and equals zero otherwise. Consistent with our hypothesis that noncompliant insiders use more of their information advantage when trading the stocks of their firms, we expect the estimated coefficients of the variable $T A X_{i t}$ to be significantly negative in the insider sales regression and significantly positive in the insider purchase regression.

\subsubsection{Control variables}

We include in our regression model several control variables, because previous research has identified several determinants of insider returns. First, we include in our model several variables measuring insider-specific determinants of insider returns. We control for an insider's age (the variable $A G E_{i}$ ), since Hillier et al. (2015) find that an insider's age affects insider trading behavior. Specifically, $A G E_{i}$ is the last two digits of an insider's birth year. We control for the observed differential trading behavior and performance by male and female insiders (e.g. Inci et al., 2014; Hillier et al., 2015) by including in our model the variable $G E N D E R_{i}$, which is a dummy variable equal to one if an insider is male, and zero otherwise.

Davidson et al. (2014) suggest that executives with a legal record have relatively low selfcontrol and respect for rules and laws, and are hence prone to use their private information to make greater returns on their insider purchases. Hence, we control for an insider's past criminal behavior by including in our models the variable $C R I M E_{i}$, which takes a value of one if an insider has been convicted or suspected of a serious crime, and otherwise zero. Following Jin and Kothari (2008), we also control for an insider's entrenchment, career concerns, and risk aversion 
with the variable $T E N U R E_{i j t}$, which is defined as the number of days since becoming an insider. In addition, since insiders in senior positions and insiders in multiple firms may have more timely access to valuable insider information than others, we control for an insider's position as a CEO (the variable $C E O_{i j t}$ ) and as a member of a board of directors (the variable BOARDMEM $M_{i j t}$ ), and the number of firms in which she is an insider (the variable NUMINS $S_{i t}$ ).

Insiders may also trade due to portfolio rebalancing and liquidity reasons and tax considerations, rather than due to the exploitation of insider information (e.g. Seyhun, 1998; Ke et al., 2003; Kallunki et al., 2009). We control for insiders' portfolio rebalancing needs with the variable $V A L U E D I V_{i j t}$, which measures the proportion of an insider's total personal wealth allocated to insider stock. ${ }^{15}$ To control for insider trading due to liquidity and taxation reasons, we include in our model the variables LIQUIDITY ${ }_{i t}$ and DECLOSS jt. LIQUIDITY $_{i t}$ is defined as the value of an insider's yearly cash holdings minus its time-series mean over the sample period, and $D E C L O S S_{j t}$ is a dummy variable equal to one if the market-adjusted buy-and-hold stock return over the past six-month period is negative and the trade is made in December, and zero otherwise. We also control for the size of an insider trade with the variable TRADEVAL $L_{i j t}$, because insider trades of a larger size may be subject to greater media and regulatory scrutiny, and thus, less motivated by informational reasons (Seyhun, 1998, p. 75).

Second, we include in our regression model several variables to control for the firm-specific determinants of insider returns. Lakonishok and Lee (2001) suggest that insiders in smaller firms earn greater returns on their stock transactions than insiders in larger firms. Hence, we control for the effect of firm size on insider returns with the variable $L N M V_{j t}$, which is the natural logarithm of the market value of equity at the end of the fiscal year prior to day $t$. In addition,

\footnotetext{
15 The reported results in Tables 6 and 7 remain unchanged if we instead use a mean-adjusted portfolio diversification measure, as in Kallunki et al. (2009).
} 
several prior studies report that insiders tend to be contrarian traders (e.g. Seyhun, 1986; Piotroski and Roulstone, 2005). Hence, we include in our model two variables to capture contrarian trading behavior: the market-adjusted buy-and-hold return over the past six-month period (the variable $M O M E N T U M_{j t}$ ), and the ratio of market value of equity to the book value of equity (the variable $P B_{j t}$ ). To control for firm profitability, we also include in our model the variable $R O A_{j t}$, defined as annual earnings deflated by total assets. ${ }^{16}$ Previous literature also suggests that the corporate control environment, including company-level black-out periods and the preapproval of trades by the general council affect insiders' opportunities to exploit their information advantage in insider trading (Bettis et al., 2000; Ravina and Sapienza, 2010; and Jagolinzer et al., 2011). Hence, we include in our models firm fixed effects $\left(F I R M_{k j}\right)$ in order to control for the effect of the control and information environment of the firm that may affect an insider's opportunities to use her insider information.

Finally, we include in our model year fixed effects $\left(Y E A R_{y}\right)$. Because our data includes multiple observations for the same firm, we control for the clustering of standard errors by firm, thereby allowing for correlation among observations for the same firm (Petersen, 2009). We also Winsorize all continuous variables to the $1^{\text {st }}$ and $99^{\text {th }}$ percentiles of their distributions, to control for potential outlier observations.

\section{Empirical results}

\subsection{Descriptive statistics and cross-correlations}

\footnotetext{
${ }^{16}$ Our results are robust to including a dummy variable for firms reporting losses (Huddart and Ke, 2007; Gao et al., 2014).
} 
Table 3 reports descriptive statistics for the variables used in the analyses, including the mean and median abnormal (market-adjusted) returns over the one-month period following insider transactions $\left(B H A R_{j t}\right)$. Consistent with previous studies (e.g. Seyhun, 1986; Lakonishok and Lee, 2001; Jagolinzer et al., 2011), we find that insider trading is informative for future stock returns. The abnormal returns following insider sale transactions are much smaller in absolute value than those following insider purchase transactions. This result likely reflects the fact that the legal and reputational risks are higher for insider sale transactions before significant drops in the stock price, compared to insider purchases before significant run-ups in the price (Cheng and Lo, 2006). Consistent with previous studies (e.g. Seyhun, 1986), insiders tend to follow a contrarian trading strategy, meaning that they buy stocks after prices have declined and sell after prices have increased. Specifically, the mean abnormal return over the six-months preceding purchases is $2.8 \%$, whereas for sales transactions it is $19.6 \%$.

\section{(Insert Table 3 about here)}

Table 4 reports the Spearman correlations between selected variables for insider sale (purchase) transactions above (below) the diagonal. The results for insider sales show significantly negative correlations between the tax noncompliance variable, $T A X_{i t}$, and the onemonth abnormal stock returns that follow insider sale transactions $\left(B H A R_{j t}\right)$. As for insider purchases, correlation coefficients between the variable $T A X_{i t}$ and the future abnormal returns are significantly positive. Regarding the other variables in Table 4, the results show that some of the correlations between variables used in Model (1) are significant, but none of them are large in magnitude. 
(Insert Table 4 about here)

\subsection{Insiders' trading behavior and tax noncompliance}

\subsubsection{Univariate analysis}

Table 5 reports the results of the unconditional univariate analyses of testing our hypothesis that noncompliant insiders exploit more of their superior information in insider trading to sell before a drop in the stock price and to buy before an increase in the stock price, compared to compliant insiders. We use the t-test (Wilcoxon test) to test whether the means (medians) of the variables are different between noncompliant and compliant insiders' trades.

Regarding insider sales, the results reported in Panel A of Table 5 show that the mean and median abnormal returns over the one-month period following insider sales are significantly lower (more negative) for noncompliant insiders, compared to compliant insiders. In particular, the mean (median) abnormal return after noncompliant insiders' sales is $-3.3 \%,(-2.8 \%)$, which is $3.28 \%(1.9 \%)$ units lower than the mean (median) abnormal return for compliant insiders, the difference being both statistically and economically significant. As for insider purchases, the results reported in Panel B of Table 5 show that noncompliant insiders' purchases earn significantly higher mean and median abnormal returns. Specificlly, the mean (median) onemonth market-adjusted stock return after noncompliant insiders' purchases is $6.3 \%$, $(3.1 \%)$, which is $4.3 \%(2.2 \%)$ units greater than the mean (median) return for compliant insiders, the difference being both statistically and economically significant. In summary, these results are consistent with our hypothesis that insiders who have not complied with the tax law are more prone to exploit their insider information when trading the stocks of their firm. 
Regarding the other variables, the results in Table 5 show that noncompliant insiders are less tenured than compliant insiders $\left(T E N U R E_{i j t}\right)$. We also find that noncompliant insiders are younger $\left(A G E_{i}\right)$, have fewer insider stockholdings in different firms $\left(N U M I N S_{i t}\right)$, and are more often employed as a $\mathrm{CEO}$ of their firm $\left(C E O_{i j t}\right)$, compared to compliant insiders. Interestingly, noncompliant insiders have been convicted or suspected of crimes significantly more often than other insiders $\left(C R I M E_{i}\right)$.

(Insert Table 5 about here)

\subsubsection{Multivariate regressions}

Table 6 reports the results of estimating Model (1) to explore whether the noncompliant insiders use more of their information advantage when trading their insider stocks, after controlling for other likely determinants of insider returns. Regarding insider sales, the results reported in Panel A of Table 6 show that the estimated coefficients of the variable for noncompliant insiders $\left(T A X_{i t}\right)$ are significantly negative, even after controlling for both insiderand firm-specific determinants of insider returns (columns 1-3). These results support our hypothesis that insiders who have shown noncompliance with the tax law are more prone to exploit their insider information at the expense of outside shareholders, compared to other insiders.

As for the control variables in Panel A of Table 6, consistent with prior literature, we find that insiders are contrarian investors $\left(M O M E N T U M_{j t}\right)$ and that the liquidity-driven insider selling is not informative for future returns $\left(\operatorname{LIQUIDITY}_{i t}\right)$. Insider selling taking place in December is likely to be more motivated by capital gain taxation considerations than by the use of superior 
information $\left(D E C L O S S_{j t}\right)$. Interestingly, we find no evidence that the insiders who have been convicted or suspected of crimes sell the stocks of their firms based on insider information $\left(C R I M E_{i}\right)$. This is consistent with Davidson et al. (2014), who find no evidence that executives with criminal records sell before price declines. Although these insiders are likely to exhibit a lower respect for the rules of society, it is possible that they perceive the probability of their insider trading being discovered as too high due to their prior history with the authorities and the legal system. This could discourage them from selling ahead of significant price declines. We also find that larger insider sale trades $\left(T R A D E V A L_{i j t}\right)$ are less predictive for future returns than smaller trades, and that insiders with multiple insider stock holdings use more of their insider information to sell before lower future returns (NUMINS $\left.S_{i t}\right)$. Regarding the firm-level control variables in Panel A, Table 6, we find that the signs of the estimated coefficients are as predicted, with one exception. Namely, the coefficient of $L N M V_{j t}$ is significantly negative in column (3), implying that insider returns decrease as the firm size increases.

The results for insider purchases are reported in Panel B of Table 6. These results show that the estimated coefficients of the variable for noncompliant insiders $\left(T A X_{i t}\right)$ is significantly positive after controlling for various insider- and firm-specific determinants of insider returns (columns 4-5), but insignificant after also controlling for firm fixed effects (column 6). Regarding the control variables in Panel B of Table 6, the results show that insiders in smaller firms $\left(L N M V_{j t}\right)$ make greater returns from their purchase transactions (e.g. Lakonishok and Lee, 2001), and that insiders tend to be contrarian investors $\left(M O M E N T U M_{j t}\right)$. The results in Table 6, Panel B, also indicate that insiders who have been convicted or suspected of crimes do not use more insider information than other insiders to make greater returns when buying insider stocks, on average $\left(C R I M E_{i}\right)$. This result is inconsistent with Davidson et al. (2014), who report that 
executives with criminal records earn greater returns from their purchase transactions. Our results are based on the archival data of all insiders, while Davidson et al. (2014) analyze a manually collected data set in which a large portion of the firms have engaged in fraud, financial reporting errors, and bankruptcy.

(Insert Table 6 about here)

We conclude our multivariate regression analyses by excluding from our sample all insider trades by insiders who have both not complied with the tax law and have been convicted or suspected of crimes. In particular, the univariate results reported in Table 5 showed that criminal behavior is significantly more prevalent among insiders who have been charged with administrative penalties by the tax authority due to noncompliance with the tax law. Since noncompliant insiders include also those who have been convicted or suspected of crimes, it is possible that criminal behavior is an underlying factor driving our results. By reducing our sample to noncompliant insiders who have not been convicted or suspected of crimes, we can mitigate this concern. An obvious shortcoming of reducing the sample is that the number of insider sells (buys) made by noncompliant insiders reduces from 207 (271) in the full sample to 70 (141) in the reduced sample. We nevertheless believe that estimating Model (1) from the reduced sample gives more insight into the results of our multivariate analyses.

Table 7 reports the results of estimating Model (1) from the reduced sample of insider trades. These results show that that the estimated coefficients of the variable for noncompliant insiders are significantly negative for insider selling (columns 1-3) and significantly positive for insider buying (columns 4-6). The signs of the control variables reported in Table 7 are also 
similar to those reported for the full sample in Table 6. Taken together, the results reported in Tables 6 and 7 support our hypothesis that insiders who have shown noncompliance with the tax law are more prone to exploit their information advantage in insider trading, compared to other insiders.

(Insert Table 7 about here)

\section{Conclusions}

In this study, we examine whether corporate insiders who have shown noncompliance with the tax law are prone to exploit their information advantage when trading the stock of their firm. Many studies in the tax compliance literature report that individuals' personal traits significantly influence their tax compliance behavior (e.g. Schwarz and Orleans, 1967; Hanno and Violette, 1996; Kaplan et al., 1997; and Henderson and Kaplan, 2005). In particular, individuals who do not comply with the tax law are more prone to ethical misconduct, and to make personal gains at the expense of others. Similar to tax noncompliance behavior, insider trading, especially insider selling, shortly before significant changes in the stock price, is widely perceived as unethical conduct, being subject both to regulatory scrutiny and reputational damages (e.g. Huddart et al., 2007; Piotroski and Roulstone, 2008).

Our results from analyzing archival data of all Swedish insiders show that insiders who have not complied with the tax law are more prone to use their information advantage to trade insider stocks before significant stock prices changes, compared to compliant insiders. These results remain after controlling for various other potential insider- and firm-specific determinants of 
insider returns, including insiders' liquidity needs, portfolio rebalancing objectives, capital gain taxation considerations, and the firm and year fixed effects.

We contribute to the literature in the following ways. First, our study expands insider trading studies that explore whether insiders' personal characteristics influence their trading behavior (Davidson et al., 2014; Skaife et al., 2013; and Hillier et al., 2015). Previous research shows that insiders differ in their willingness to take advantage of their informational advantage in the stock market. However, there is little evidence on the specific person-level determinants of this behavior. Our study helps to fill this gap. Second, we extend the tax noncompliance literature by linking individuals' tax noncompliance behavior with their other questionable behavior. While many studies show that taxpayers' personal attitudes towards ethical misconduct influence their tax noncompliance behavior, little is known about whether such behavior is reflected in adverse behavior by corporate executives. We believe that our results are of interest to regulatory authorities who design monitoring mechanisms for insider trading. For instance, our results imply that regulatory authorities may benefit from sharing information on insiders with tax authorities in order to identify insiders who are likely to trade their insider stocks before significant price changes. 
Appendix 1. Swedish insider legislation

Insider legislation has existed in Sweden since 1985, when the first law prohibiting trading in securities while in possession of non-public, company-related information was passed. This law was initially enforced in 1989, when Sweden got its first conviction for illegal insider trading, and regulations were further tightened in 1991 as the European Union Directive on the Regulation of Insider Trading (EEC Directive 89/592) was incorporated into Swedish law. Insider trading in Sweden is regulated by the Finansinspektionen, which is the corresponding authority to the SEC in the United States. Similarly to U.S. insiders who have to file their insider trades with the SEC, insiders in Sweden are required to report their insider holdings and insider stock trades to the Finansinspektionen, in accordance with The Act Concerning Reporting Obligations for Certain Holdings of Financial Instruments (2000:1087). The Finansinspektionen publishes the information on insiders' trades on a daily basis on their website. The reporting obligation period for insider trades in Sweden is five business days from the day of the trades, as of January 2001, while in the U.S. it is two days, as of August 2002.

During our study period, the Market Abuse Penal Act (2005:377) complying with the EEC Directive 2003/6/EC on insider dealing and market manipulation was enforced. In addition, as of June 2005, Swedish insiders are prohibited from trading in the firm's shares 30 days prior to the publication of earnings announcements. This trading ban replaced the short-term trading rule (effective since 1997) under which insiders were not allowed to engage in a round-trip transaction (e.g. a buy followed by a sale) during a three-month trading window. In comparison, insiders in the U.S. are penalized for trading profits earned fewer than six months subsequent to previous trades ("the short-swing rule" of the Section 16(b) of the Securities and Exchange Act 
of 1934), but there is no legal rule that prohibits insiders from trading prior to earnings announcements. 
Appendix 2. Variables used in the analyses

\begin{tabular}{|c|c|c|}
\hline Variable & Description & Data Source \\
\hline$B H A R_{j t}$ & $\begin{array}{l}\text { The abnormal (market-adjusted) buy-and-hold stock return for the one-month } \\
\text { period following an insider trade that takes place on day } t \text { for firm } j \text {. }\end{array}$ & Thomson Datastream \\
\hline$T A X_{i t}$ & $\begin{array}{l}\text { The sum of the SEK value of total administrative penalties imposed by the } \\
\text { Skatteverket for insider } i \text { due to noncompliance with the tax law in the year } \\
\text { preceding day } t \text {, and zero otherwise. The SEK value of total administrative } \\
\text { penalties is the sum of the failure-to-file penalty and the surcharge penalty. } \\
\text { Regression analyses use the natural logarithm of }\left(1+T A X_{i t}\right) \text {. }\end{array}$ & $\begin{array}{l}\text { The Swedish Tax } \\
\text { Agency }\end{array}$ \\
\hline$C R I M E_{i}$ & $\begin{array}{l}\text { A dummy variable equal to one if insider } i \text { has been found guilty of a crime(s) } \\
\text { in a court of law or received summary punishments by prosecutors, or has been } \\
\text { suspected of a serious crime(s), and otherwise zero. Convictions include all } \\
\text { convictions since } 1974 \text { and suspicions include all suspicions since } 1991 .\end{array}$ & $\begin{array}{l}\text { The Swedish National } \\
\text { Council for Crime } \\
\text { Prevention; The Swedish } \\
\text { National Police Board }\end{array}$ \\
\hline GENDER & A dummy variable equal to one if insider $i$ is male, and zero otherwise. & $\begin{array}{l}\text { The Nordic Central } \\
\text { Securities Depository }\end{array}$ \\
\hline$T E N U R E_{i j t}$ & $\begin{array}{l}\text { The number of days since an insider } i \text { became an insider in firm } j \text { on day } t \text {. } \\
\text { Regression analyses use the natural logarithm of }\left(1+T E N U R E_{i j t}\right) \text {. }\end{array}$ & $\begin{array}{l}\text { The Swedish Financial } \\
\text { Supervisory Authority }\end{array}$ \\
\hline$C E O_{i j t}$ & $\begin{array}{l}\text { A dummy variable equal to one if insider } i \text { has an insider position as a chief } \\
\text { executive officer of firm } j \text { on day } t \text {, and zero otherwise. }\end{array}$ & $\begin{array}{l}\text { The Swedish Financial } \\
\text { Supervisory Authority }\end{array}$ \\
\hline$B O A R D M E M_{i j t}$ & $\begin{array}{l}\text { A dummy variable equal to one if insider } i \text { has an insider position as a member } \\
\text { of the board of directors of firm } j \text { on day } t \text {, and zero otherwise. }\end{array}$ & $\begin{array}{l}\text { The Swedish Financial } \\
\text { Supervisory Authority }\end{array}$ \\
\hline$A G E_{i}$ & $\begin{array}{l}\text { The last two digits of insider } i \text { 's birth year. Regression analyses use the natural } \\
\text { logarithm of } A G E_{i} \text {. }\end{array}$ & $\begin{array}{l}\text { The Nordic Central } \\
\text { Securities Depository }\end{array}$ \\
\hline$T R A D E V A L_{i j t}$ & $\begin{array}{l}\text { The value of insider } i \text { 's sale or purchase trade on insider stock } j \text { on day } t \text {. } \\
\text { Regression analyses use the natural logarithm of TRADEVALijt. }\end{array}$ & $\begin{array}{l}\text { The Swedish Financial } \\
\text { Supervisory Authority }\end{array}$ \\
\hline$V A L U E D I V_{i j t}$ & $\begin{array}{l}\text { The value of insider } i \text { 's holdings in insider stock } j \text { at the end of the previous } \\
\text { fiscal year prior to day } t \text {, divided by the value of insider } i \text { 's personal wealth }\end{array}$ & $\begin{array}{l}\text { The Nordic Central } \\
\text { Securities Depository } \\
\text { Group and the Swedish }\end{array}$ \\
\hline
\end{tabular}




\begin{tabular}{|c|c|c|}
\hline & from the previous fiscal year prior to day $t$. & Tax Agency \\
\hline LIQUIDITY $_{i t}$ & $\begin{array}{l}\text { The value of insider } i \text { 's cash holdings at the end of the fiscal year prior to day } \\
t \text {, minus its time-series mean calculated for insider } i \text { over the sample period. } \\
\text { Regression analyses use the natural logarithm of }\left(1+\text { LIQUIDITY }_{i t}\right) \text {. }\end{array}$ & $\begin{array}{l}\text { The Swedish Tax } \\
\text { Agency }\end{array}$ \\
\hline$N_{U M I N S}{ }_{i t}$ & $\begin{array}{l}\text { The number of firms in which an insider } i \text { is an insider at the end of fiscal year } \\
\text { prior to day } t \text {. Regression analyses use the natural logarithm of }\left(1+N U M I N S_{i t}\right)\end{array}$ & $\begin{array}{l}\text { The Nordic Central } \\
\text { Securities Depository } \\
\text { Group }\end{array}$ \\
\hline$D E C L O S S_{j t}$ & $\begin{array}{l}\text { A dummy variable equal to one if the market-adjusted buy-and-hold stock } \\
\text { return for the six-month period prior to day } t \text { for firm } j \text { is negative and day } t \text { is } \\
\text { in December, and zero otherwise. }\end{array}$ & Thomson Datastream \\
\hline MOMENTUM ${ }_{i t}$ & $\begin{array}{l}\text { The abnormal (market-adjusted) buy-and-hold return for firm } j \text { for the six- } \\
\text { month period prior to day } t \text {. }\end{array}$ & Thomson Datastream \\
\hline$R O A_{j t}$ & $\begin{array}{l}\text { The ratio of annual earnings for firm } j \text { to total assets from the fiscal year prior } \\
\text { to day } t \text {. }\end{array}$ & Thomson Datastream \\
\hline$L N M V_{j t}$ & $\begin{array}{l}\text { The natural logarithm of the market value of shares for firm } j \text { multiplied by the } \\
\text { number of shares outstanding from the fiscal year prior to day } t \text {. }\end{array}$ & Thomson Datastream \\
\hline$P B_{j t}$ & $\begin{array}{l}\text { The ratio of market value of shares for firm } j \text { to the book value of equity from } \\
\text { the fiscal year prior to day } t \text {. }\end{array}$ & Thomson Datastream \\
\hline$L O S S_{j t}$ & $\begin{array}{l}\text { A dummy variable equal to one if the annual earnings for firm } j \text { are negative in } \\
\text { the fiscal year prior to day } t \text {, and zero otherwise. }\end{array}$ & Thomson Datastream \\
\hline$Y E A R \_y$ & The eight yearly dummy variables for the years 2000 to 2007 . & Thomson Datastream \\
\hline$F I R M \_k_{j}$ & The dummy variables for each firm. & Thomson Datastream \\
\hline
\end{tabular}

Notes:

Appendix 2 presents the descriptions of all the variables used in the analyses. We address the presence of influential/outlier observations in the data by Winsorizing all continuous variables at the $1^{\text {st }}$ and $99^{\text {th }}$ percentiles of their distributions. 


\section{Acknowledgements}

The authors would like to thank the seminar participants at Norwegian School of Economics in Bergen, University of Oulu, and the $5^{\text {th }}$ Workshop on Current Research in Taxation in Prague, and the conference participants at the $38^{\text {th }}$ Annual Congress of the European Accounting Association in Glasgow, and the 2014 Nordic Accounting Conference in Copenhagen for their useful comments and suggestions. The authors also thank Euroclear Sweden, Finansinspektionen, the Swedish Tax Authorities, and the Swedish Research Council for providing the requisite data. This study has been evaluated and approved by the Regional Ethical Review Board in Umeå, Sweden (DNR 08:074 Ö and DNR I3-0449/2009). The authors gratefully acknowledge financial support from the NASDAQ OMX Nordic Foundation, Vetenskapsrådet, the Handelsbanken Research Foundation, the Finnish Savings Banks Group Research Foundation, the Marcus Wallenberg Research Foundation, the Finnish Cultural Foundation, and the Academy of Finland [Project \#243017121]. 


\section{References}

Aboody, D., Hughes, J. Liu, J., 2005. Earnings quality, insider trading, and cost of capital. Journal of Accounting Research 43, 651-673.

Agrawal, A., Nasser, T., 2012. Insider trading in takeover targets. Journal of Corporate Finance $18,598-625$.

Aggarwal, R., Erel, I., Williamson, R., Stultz, R., 2009. Differences in governance practices between US and foreign firms: measurement, causes, and consequences. Review of Financial Studies 22, 3131-3169.

Alexander, C., Feinstein, J.S., 1987. A microeconomic analysis of income tax evasion. Mimeo, MIT.

Allingham, M.G., Sandmo, A., 1972. Income tax evasion: A theoretical analysis. Journal of Public Economics 1, 323-338.

Alm, J., McClelland, B.R., Schulze, W.D., 1992. Why do people pay taxes. Journal of Public Economics 48, 21-38.

Alm, J., Torgler, B., 2006. Culture differences and tax morale in the United States and in Europe. Journal of Economic Psychology 27(2), 224-246.

Badertscher, B.A., Hribar, S.P., Jenkins, N.T., 2011. Informed trading and the market reaction to accounting restatements. The Accounting Review 86(5), 1519-1547.

Beams, J.D., Brown, R.M., Killough, L.N., 2003. An experiment testing the determinants of noncompliance with insider trading laws. Journal of Business Ethics 45(4), 309-323.

Beny, L.N., 2005. Do insider trading laws matter? Some preliminary comparative evidence. American Law and Economics Review 7(1), 144-183. 
Bettis, J.C., Coles, J.L., Lemmon, M.L., 2000. Corporate policies restricting trading by insiders. Journal of Financial Economics 57(2), 191-220.

Bhattacharya, U., Daouk, H., Welker, M., 2002. The world price of insider trading. The Journal of Finance 57(1), 75-108.

Bhattacharya, U., Marshall, C.D., 2012. Do they do it for the money? Journal of Corporate Finance 18(1), 92-104.

Bobek, D.D., Hatfield, R.C., 2003. An investigation of the theory of planned behavior and the role of moral obligation in tax compliance. Behavioral Research In Accounting 15(1), 13-38.

Bonaime, A. A., Ryngaert, M. D., 2013. Insider trading and share repurchases: Do insiders and firms trade in the same direction?. Journal of Corporate Finance 22, 35-53.

Bris, A., 2005. Do insider trading laws work? European Financial Management 11, 267-312.

Brochet, F., 2010. Information content of insider trades before and after the Sarbanes-Oxley Act. The Accounting Review 85(2), 419-446.

Brockman, P., Tresl, J., Unlu, E., 2014. The impact of insider trading laws on dividend payout policy. Journal of Corporate Finance 29, 263-287.

Denis, D. J., Xu, J., 2013. Insider trading restrictions and top executive compensation. Journal of Accounting and Economics 56(1), 91-112.

Burton, H.A., Karlinsky, S.S., Blanthorne, C., 2005. Perception of a white-collar crime: Tax evasion. The ATA Journal of Legal Tax Research 3(1), 35-48.

Cheng, Q., Lo, K., 2006. Insider trading and voluntary disclosures. Journal of Accounting Research 44(5), 815-848.

Chyz, J.A., 2013. Personally tax aggressive executives and corporate tax sheltering. Journal of Accounting and Economics 56(2), 311-328. 
Collins, J.H., Milliron, V.C., Toy, D.R., 1992. Determinants of tax compliance: A contingency approach. The Journal of the American Taxation Association 14, 1-29.

Davidson, R., Dey, A., Smith, A.J., 2014. Executives' legal records, lavish lifestyles and insider trading activities. University of Chicago Working Paper.

Erard, B., Feinstein, J.S., 1994. Honesty and Evasion in the Tax Compliance Game. The RAND Journal of Economics 25(1), 1-19.

Gao, F., Ling Lei Lisic, L.L., Ivy Xiying Zhang, I.X., 2014. Commitment to social good and insider trading. Journal of Accounting and Economics 57(2), 149-175.

Garfinkel, J. A., 1997. New evidence on the effects of federal regulations on insider trading: the Insider Trading and Securities Fraud Enforcement Act (ITSFEA). Journal of Corporate Finance 3(2), 89-111.

Ghosh, D., Crain, T.L., 1996. Experimental investigation of ethical standards and perceived probability of audit on intentional noncompliance. Behavioral Research in Accounting 8, 219244.

Graetz, M.J., Reingaum, J.F., Wilde, L.L., 1986. The tax compliance game: Toward an interactive theory of law enforcement. Journal of Law, Economics, and Organization 2, 1-32.

Grasmick, H.G., Bursick, R.J., 1990. Conscience, significant others, and rational choice: Extending the deterrence model. Law and Society Review 24(3), 837-862.

Grasmick, H.G., Scott, W.J., 1982. Tax evasion and mechanisms of social control: A comparison with grand and petty theft. 2(3), 213-230.

Hanno, D.M., Violette, G.R., 1996. An analysis of moral and social influences on taxpayer behavior. Behavioral Research in Accounting 8, 57-75. 
Henderson, B.C., Kaplan, S.E., 2005. An examination of the role of ethics in tax compliance decisions. The Journal of the American Taxation Association, 27(1), 39-72.

Hillier, D., Marshall, A.P., 2002. Are trading bans effective? Exchange regulation and corporate insider transactions around earnings announcements. Journal of Corporate Finance 8, 393410.

Hillier, D., Korczak, A., Korczak, P., 2015. The impact of personal attributes on corporate insider trading. Journal of Corporate Finance 30, 150-167.

Huddart, S., Ke, B., 2007. Information asymmetry and cross-sectional variation in insider trading. Contemporary Accounting Research 24(1), 195-232.

Huddart, S., Ke, B., Shi, C., 2007. Jeopardy, non-public information, and insider trading around SEC 10-K and 10-Q filings. Journal of Accounting and Economics 43(1), 3-36.

Inci, A.C., Narayanan, M.P., Seyhun, H.N., 2014. Gender differences in executives' access to information. Ross School of Business Working Paper.

Internal Revenue Service, 2012. Overview of the tax gap for tax year 2006. Available: https://www.irs.gov/pub/irs-soi/06rastg12overvw.pdf [Accessed 21 November 2015].

Jagolinzer, A.D., Larcker, D.F., Taylor, D.J., 2011. Corporate governance and the information content of insider trades. Journal of Accounting Research 49(5), 1249-1274.

Jin, L., Kothari, S.P., 2008. Effect of personal taxes on managers' decision to sell their stock. Journal of Accounting and Economics 46(1), 23-46.

Kallunki, J-P., Nilsson, H., Hellström, J., 2009. Why do insiders trade? Evidence based on unique data on Swedish insiders. Journal of Accounting and Economics 48(1), 37-53. 
Kaplan, S.E., Newberry, K.J., Reckers, P.M.J., 1997. The effect of moral reasoning and educational communications on tax evasion intentions. The Journal of American Taxation Association 19(2), 38-54.

Kaplan, S.E., Samuels, J.A., Thorne, L., 2009. Ethical norms of CFO insider trading. Journal of Accounting and Public Policy 28(5), 386-400.

Ke, B., Huddart, S., Petroni, K., 2003. What insiders know about future earnings and how they use it: Evidence from insider trades. Journal of Accounting and Economics 35(3), 315-346.

Kohlberg, L., 1969. Stages and sequences: The cognitive developmental approach to socialization. In D. Goslin, ed., Handbook of Socialization Theory and Research. Chicago, IL: Rand McNally.

Korsell, L. (2001). Three decades of researching and combating economic crime: The Swedish case. In S. A. Lindgren (Ed.), White-collar crime research. Old views and future potentials (pp. 91-106). Stockholm: The National Council for Crime Prevention.

Kraft, A., Lee, B.S., Lopatta, K., 2014, Management earnings forecasts, insider trading, and information asymmetry. Journal of Corporate Finance 26, 96-123.

Kyle, A.S., 1985. Continuous auctions and insider trading. Econometrica, 1315-1335.

Lakonishok, J., Lee, I., 2001. Are insider trades informative? Review of Financial Studies 14(1), 79-11.

Moore, J., 1990. What is really unethical about insider trading? Journal of Business Ethics 9(3), 171-182.

Lee, I., Lemmon, M., Li, Y., Sequeira, J.M., 2014. Do voluntary corporate restrictions on insider trading eliminate informed insider trading? Journal of Corporate Finance 29, 158-178. 
Petersen, M.A., 2009. Estimating standard errors in finance panel data sets: Comparing approaches. The Review of Financial Studies 22(1), 435-480.

Piotroski, J.D., Roulstone, D.T., 2005. Do insider trades reflect both contrarian beliefs and superior knowledge about future cash flow realizations? Journal of Accounting and Economics 39(1), 55-81.

Piotroski, J.D., Roulstone, D.T., 2008. Evidence on the non-linear relation between insider trading decisions and future earnings information. The Journal of Law, Economics and Policy 4, 409 .

Ravina, E., Sapienza, P., 2010. What do independent directors know? Evidence from their trading. The Review of Financial Studies 23(3), 962-1003.

Reckers, P.M.J., Sanders, D.L., Roark, S.J., 1994. The influence of ethical attitudes on taxpayer compliance. National Tax Journal 47(4), 825-836.

Rozeff, M.S., Zaman, M.A., 1998. Overreaction and insider trading: Evidence from growth and value portfolios. The Journal of Finance 53(2), 701-716.

Schwartz, R.D., Orleans., S., 1967. On legal sanctions. University of Chicago Law Review 34, 274-300.

SEC., 2013. How Investigations Work. Available: http://www.sec.gov/News/Article/Detail/Article/1356125787012 [Accessed 21 November 2015].

Seyhun, H.N., 1986. Insiders' profits, costs of trading, and market efficiency. Journal of Financial Economics 16(2), 189-212.

Seyhun, N., 1998, Investment intelligence from insider trading. MIT Press, Cambridge, MA. 
Shefrin, S.M., Triest, R.K., 1992. Can brute deterrence backfire? Perceptions and attitudes in taxpayer compliance. In J. Slemrod, ed., Why people pay taxes: Tax compliance and enforcement. Ann Arbor: University of Michigan Press, 1992.

Skaife, H.A., Veenman, D., Wangerin, D., 2013. Internal control over financial reporting and managerial rent extraction: Evidence from the profitability of insider trading. Journal of Accounting and Economics 55(1), 91-110.

Song, Y., Yarbrough, T.E., 1978. Tax ethics and taxpayers attitudes: A survey. Public Administration Review 38(5), 442-452.

Srinivasan, T.N., 1973. Tax evasion: A model. Journal of Public Economics 2, 339-346.

Swedish Tax Agency, 2010. An English Summary of Tax Statistical Yearbook of Sweden 2010. Available:

http://www.skatteverket.se/download/18.616b78ca12d1247a4b2800025728/1359707291988/ 10411.pdf [Accessed 21 November 2015].

Swedish Tax Agency, 2011. Tax Statistical Yearbook of Sweden 2011. Available: https://www.skatteverket.se/download/18.5fc8c94513259a4ba1d800065202/15214.pdf [Accessed 21 November 2015].

Tsakumis, G.T., Curatola, A.P., Porcano, T.M., 2007. The relation between national cultural dimensions and tax evasion. Journal of International Accounting, Auditing and Taxation 16(2), 131-147.

Vogel, J., 1974. Taxation and public opinion in Sweden: An interpretation of recent data. National Tax Journal 27(4), 499-514.

Xiao, G., 2015. Trading and earnings management: Evidence from China's non-tradable share reform. Journal of Corporate Finance 31, 67-90. 


\title{
Table 1
}

\section{Summary statistics on Swedish insiders}

\author{
$\mathrm{N}($ Total $=3,392)$
}

$\%$

\section{Panel A: Gender and age}

Gender:

\begin{tabular}{lrr} 
Males & 2,857 & 84.23 \\
Females & 535 & 15.77 \\
\hline Total & 3,392 & 100.00 \\
& & \\
Age (year of birth): & & \\
$<1950$ & 995 & 29.33 \\
$1950-1959$ & 1,107 & 32.64 \\
$1960-1969$ & 1,000 & 29.48 \\
$\geq 1970$ & 290 & 8.55 \\
\hline Total & 3,392 & 100.00
\end{tabular}

Panel B: Position as an insider

CEO

Board member

Other position

Total

3,392

100.00

\begin{tabular}{lcrrrr} 
Panel C: Insider trading activity & \multicolumn{1}{l}{} \\
\hline Description & Mean & Median & St.dev. & Min & Max \\
\hline \# of sale transaction & 3.188 & 2.000 & 7.257 & 1.000 & 211.000 \\
Value of a sale transaction & 5,128 & 313 & 38,355 & 10 & $1,605,000$ \\
& & & & & \\
\# of purchase transactions & 3.528 & 2.000 & 10.712 & 1.000 & 310.000 \\
Value of a purchase transaction & 2,933 & 151 & 23,090 & 10 & 945,029 \\
\hline
\end{tabular}

Notes:

1. The table reports summary statistics on insiders and their trading activity on insider stocks. The sample includes all 3,392 insiders in all 394 listed firms in Sweden with at least one insider transaction over the period 2000-2008. Panels A and B report the distributions of insiders' gender, age, and position as an insider. Panel $\mathrm{C}$ reports the distributions of the number and value of 5,610 insider sale and 9,096 purchase transactions during the sample period.

2. Transaction value is in thousands of SEK. 1 SEK is equal to 0.12 USD. 


\section{Table 2}

\section{Summary statistics on insiders' tax noncompliance behavior}

Panel A: Administrative penalties due to tax noncompliance

\begin{tabular}{lcc}
\hline & $\mathrm{N}($ Total = 3,392) & $\%$ \\
\cline { 2 - 3 } Not complied with the tax law & 142 & 4.19 \\
Type of administrative penalty charged & $\mathrm{N}($ Total = 142) \\
\cline { 2 - 3 } & 112 & 78.89 \\
Failure-to-file penalty & 43 & 30.28 \\
Surcharge penalty & 13 & 9.15 \\
Both failure-to-file penalty and surcharge & & \\
\hline
\end{tabular}

Panel B: Descriptive statistics on the administrative penalties

\begin{tabular}{lrrrrr}
\hline Description & Mean & Median & St.dev. & Min & Max \\
\hline Total administrative penalties (N=179) & 53,613 & 2,000 & 365,679 & 500 & $3,828,534$ \\
Type of administrative penalty charged & & & & & \\
& & & & & \\
Failure-to-file penalty (N = 148) & 1,375 & 1,000 & 707 & 500 & 3,000 \\
Surcharge penalty (N = 45) & 208,740 & 8,271 & 712,252 & 516 & $3,826,534$ \\
\hline
\end{tabular}

Notes:

1. The table reports summary statistics on insiders' tax noncompliance behavior. The sample includes all 3,392 insiders in all 394 listed firms in Sweden with at least one insider transaction over the period 2000-2008. Panel A reports the total number of insiders who have been charged with administrative penalties by the Skatteverket (the Swedish Tax Agency) due to noncompliance with the tax law in the year preceding their insider trades. Panel A also reports the number of insiders who have been charged with an administrative penalty according to the type of penalty received: a failureto-file penalty, surcharge penalty, or both. Panel B reports descriptive statistics on the SEK value of the administrative penalties assessed to insiders by the Skatteverket due to violations of the tax law (Taxation Act 1990:324).

2. The distributions of total administrative penalties charged (the sum of a failure-to-file penalty and a surcharge penalty), and failure-to-file penalties and surcharge penalties, are based on the 179, 45, and 148 insider-year observations, respectively, in which an insider was charged with an administrative penalty by the Skatteverket.

3. $1 \mathrm{SEK}$ is equal to $0.12 \mathrm{USD}$. 


\section{Table 3}

Descriptive statistics of the variables used in the analyses

\begin{tabular}{|c|c|c|c|c|c|}
\hline Variable & Mean & Median & St.dev. & Min & Max \\
\hline \multicolumn{6}{|c|}{ Panel A: Insider sales transactions $(N=5,610)$} \\
\hline$B H A R_{j t}$ & $-\mathbf{0 . 0 0 3 *}$ & $-0.009++$ & 0.130 & -0.333 & 0.511 \\
\hline MOMENTUM $M_{j t}$ & $0.196++$ & $0.106++$ & 0.515 & -0.674 & 2.738 \\
\hline$T A X_{i t}$ & 3.000 & 0.000 & 78.000 & 0.000 & 3,829 \\
\hline$C R I M E_{i}$ & 0.331 & 0.000 & 0.471 & 0.000 & 1.000 \\
\hline$A G E_{i}$ & 54.000 & 54.000 & 9.286 & 20.000 & 86.000 \\
\hline$G_{E N D E R_{i}}$ & 0.914 & 1.000 & 0.281 & 0.000 & 1.000 \\
\hline$T E N U R E_{i j t}$ & 1,691 & 1,365 & 1,252 & 0.000 & 8,155 \\
\hline$C E O_{i j t}$ & 0.093 & 0.000 & 0.290 & 0.000 & 1.000 \\
\hline$B_{O A R D M E M_{i j t}}$ & 0.430 & 0.000 & 0.495 & 0.000 & 1.000 \\
\hline$T R A D E V A L_{i j t}$ & 3,554 & 313 & 13,173 & 12.000 & 104,912 \\
\hline$V A L U E D I V_{i j t}$ & 0.327 & 0.161 & 0.363 & 0.000 & 1.000 \\
\hline LIQUIDITY $_{i t}$ & 1,535 & -62 & 22,999 & $-35,256$ & 410,370 \\
\hline$D E C L O S S_{j t}$ & 0.042 & 0.000 & 0.200 & 0.000 & 1.000 \\
\hline$N U M I N S_{i t}$ & 1.320 & 1.000 & 1.442 & 0.000 & 8.000 \\
\hline$R O A_{j t}$ & -0.014 & 0.044 & 0.289 & -1.611 & 0.549 \\
\hline$L N M V_{j t}$ & 0.164 & 0.020 & 2.126 & -6.215 & 6.976 \\
\hline$P B_{j t}$ & 3.808 & 2.362 & 4.016 & 0.334 & 23.027 \\
\hline \multicolumn{6}{|c|}{ Panel B: Insider purchase transactions $(N=9,096)$} \\
\hline$B H A R_{j t}$ & $0.021++$ & $0.010++$ & 0.124 & -0.280 & 0.523 \\
\hline MOMENTUM $M_{j t}$ & $0.028++$ & $0.008++$ & 0.307 & -0.702 & 1.115 \\
\hline$T A X_{i t}$ & 2.000 & 0.000 & 33.000 & 0.000 & 2,237 \\
\hline$C R I M E_{i}$ & 0.343 & 0.000 & 0.475 & 0.000 & 1.000 \\
\hline$A G E_{i}$ & 53.000 & 53.000 & 9.585 & 20.000 & 82.000 \\
\hline$G_{E N D E R_{i}}$ & 0.903 & 1.000 & 0.295 & 0.000 & 1.000 \\
\hline TENURE $E_{i j t}$ & 1,467 & 1,017 & 1,451 & 0.000 & 8,428 \\
\hline$C E O_{i t}$ & 0.126 & 0.000 & 0.332 & 0.000 & 1.000 \\
\hline BOARDMEM $M_{i j t}$ & 0.518 & 1.000 & 0.500 & 0.000 & 1.000 \\
\hline TRADEVAL $L_{i j t}$ & 1,907 & 151 & 7,436 & 11.000 & 60,250 \\
\hline$V A L U E D I V_{i j t}$ & 0.137 & 0.013 & 0.247 & 0.000 & 1.000 \\
\hline LIQUIDITY $_{i t}$ & -276 & -46 & 24,253 & $-214,565$ & 302,037 \\
\hline$D E C L O S S_{j t}$ & 0.056 & 0.000 & 0.230 & 0.000 & 1.000 \\
\hline$N_{U M I N S}{ }_{i t}$ & 1.238 & 1.000 & 1.499 & 0.000 & 8.000 \\
\hline$R O A_{j t}$ & -0.006 & 0.042 & 0.230 & -1.258 & 0.508 \\
\hline$L N M V_{j t}$ & 0.548 & 0.223 & 2.279 & -6.215 & 6.976 \\
\hline
\end{tabular}




\begin{tabular}{llllll}
\hline$P B_{j t}$ & 2.930 & 1.999 & 2.973 & 0.410 & 18.269 \\
\hline
\end{tabular}

Notes:

1. The table reports descriptive statistics of the variables used in the analyses. The sample includes all 3,392 insiders in all 394 listed firms in Sweden with at least one insider transaction over the period 2000-2008. Panel A (Panel B) reports descriptive statistics for 5,610 $(9,096)$ insider sale (purchase) transactions. All variables are defined as in Appendix 2. All continuous variables are Winsorized to the $1^{\text {st }}$ and $99^{\text {th }}$ percentiles of their distributions. The variables TAX $X_{i t}, T R A D E V A L_{i j t}$, and LIQUIDITY $Y_{i t}$ are in thousands of SEK. 1 SEK is equal to 0.12 USD.

2. For the abnormal (market-adjusted) return following insider transactions (the variable $B H A R_{j t}$ ) and the past abnormal (market-adjusted) returns (the variable $M O M E N T U M_{j t}$ ), we test for a difference from zero using the $t$-test (Wilcoxon rank-sum test) for means (medians).

3. $*,+$, and ++ denote a statistically significant difference at the $0.10,0.05$, and 0.01 (two-tailed) level, respectively. 


\section{Table 4}

\section{Correlation matrix for selected variables}

\begin{tabular}{|c|c|c|c|c|c|c|c|c|c|c|c|c|c|}
\hline & & 1 & 2 & 3 & 4 & 5 & 6 & 7 & 8 & 9 & 10 & 11 & 12 \\
\hline 1 & $B H A R_{j t}$ & & -0.02 & 0.00 & -0.02 & -0.04 & -0.01 & 0.04 & -0.04 & 0.02 & 0.06 & 0.08 & -0.10 \\
\hline 2 & $A G E_{i}$ & 0.01 & & -0.12 & 0.02 & 0.02 & -0.04 & -0.07 & -0.01 & -0.17 & 0.08 & 0.01 & 0.10 \\
\hline 3 & $G_{E N D E R_{i}}$ & 0.01 & -0.17 & & -0.02 & 0.05 & 0.16 & 0.14 & 0.04 & 0.08 & -0.04 & -0.09 & -0.04 \\
\hline 4 & $M O M E N T U M_{j t}$ & 0.00 & -0.02 & 0.02 & & -0.04 & -0.02 & 0.11 & 0.00 & 0.03 & 0.10 & -0.01 & -0.03 \\
\hline 5 & $T A X_{i t}$ & 0.04 & 0.05 & 0.01 & 0.03 & & 0.14 & 0.07 & -0.01 & 0.01 & -0.03 & -0.03 & -0.03 \\
\hline 6 & $C R I M E_{i}$ & 0.01 & -0.01 & 0.18 & 0.02 & 0.05 & & 0.07 & -0.03 & -0.04 & -0.05 & -0.09 & -0.03 \\
\hline 7 & $T R A D E V A L_{i j t}$ & -0.01 & -0.16 & 0.19 & 0.08 & -0.03 & 0.13 & & -0.03 & 0.16 & 0.19 & 0.32 & 0.09 \\
\hline 8 & $V A L U E D I V_{i j t}$ & 0.01 & -0.11 & 0.09 & 0.02 & 0.03 & -0.10 & 0.09 & & 0.28 & 0.05 & -0.08 & 0.13 \\
\hline 9 & $N U M I N S_{i t}$ & -0.00 & -0.22 & 0.10 & -0.01 & 0.01 & -0.04 & 0.27 & 0.53 & & 0.09 & 0.11 & -0.05 \\
\hline 10 & $R O A_{j t}$ & -0.02 & 0.07 & -0.07 & 0.08 & -0.09 & -0.01 & 0.12 & 0.12 & 0.08 & & 0.42 & 0.15 \\
\hline 11 & $L N M V_{j t}$ & -0.05 & 0.00 & -0.10 & -0.03 & -0.10 & -0.06 & 0.20 & 0.08 & 0.17 & 0.46 & & 0.20 \\
\hline 12 & $P B_{j t}$ & -0.04 & 0.07 & -0.06 & -0.07 & -0.03 & -0.07 & 0.02 & 0.06 & -0.02 & 0.11 & 0.20 & \\
\hline
\end{tabular}

Notes:

1. The table reports pair-wise Spearman correlations between selected variables used in the analyses for the sample of 5,610 $(9,096)$ insider sale (purchase) transactions above (below) the diagonal. The sample includes all 3,392 insiders in all 394 listed firms in Sweden with at least one insider transaction over the period 2000-2008.

2. Correlations above 0.02 and below -0.02 are significant at the 0.10 level or better.

3. All variables are defined as in Appendix 2. All continuous variables are Winsorized to the $1^{\text {st }}$ and $99^{\text {th }}$ percentiles of their distributions. 


\section{Table 5}

\section{Univariate analyses of insider trades and tax noncompliance behavior}

Tax noncompliance behavior

\begin{tabular}{|c|c|c|c|c|c|c|}
\hline \multirow[b]{2}{*}{ Variable } & \multicolumn{2}{|c|}{ Noncompliant insiders } & \multicolumn{2}{|c|}{ Compliant insiders } & \multicolumn{2}{|c|}{ Test for difference } \\
\hline & Mean & Median & Mean & Median & Mean & Median \\
\hline \multicolumn{7}{|c|}{ Panel A: Insider sale transactions } \\
\hline$B H A R_{j t}$ & -0.033 & -0.028 & -0.002 & -0.009 & $3.30++$ & $-3.11++$ \\
\hline$M O M E N T U M_{j t}$ & 0.135 & 0.018 & 0.199 & 0.107 & $1.90 *$ & $-2.60++$ \\
\hline$C R I M E_{i}$ & 0.662 & 1.000 & 0.319 & 0.000 & $-10.40++$ & $10.30++$ \\
\hline$A G E_{i}$ & 55.000 & 57.000 & 54.000 & 54.000 & $-1.85 *$ & 1.59 \\
\hline$G E N D E R_{i}$ & 0.990 & 1.000 & 0.911 & 1.000 & $-10.12++$ & $3.99++$ \\
\hline$T_{E N U R E_{i j t}}$ & 1,392 & 1,159 & 1,702 & 1,380 & $4.06++$ & $-3.60++$ \\
\hline$C E O_{i j t}$ & 0.135 & 0.000 & 0.091 & 0.000 & $-1.83 *$ & $2.15+$ \\
\hline$B O A R D M E M_{i j t}$ & 0.536 & 1.000 & 0.426 & 0.000 & $-3.15++$ & $3.15++$ \\
\hline$T R A D E V A L_{i j t}$ & 4,993 & 744 & 3,499 & 305 & -1.60 & $5.07++$ \\
\hline$V A L U E D I V_{i j t}$ & 0.333 & 0.099 & 0.326 & 0.163 & -0.26 & -0.40 \\
\hline $\operatorname{LIQUIDITY}_{i t}$ & $-67,424$ & $-64,013$ & $1,596,698$ & $-61,784$ & $4.92++$ & 0.18 \\
\hline$\widetilde{D E C L O S S} S_{j t}$ & 0.063 & 0.000 & 0.041 & 0.000 & -1.28 & 1.55 \\
\hline$N U M I N S_{i t}$ & 1.116 & 1.000 & 1.328 & 1.000 & $3.90++$ & 0.88 \\
\hline $\mathrm{N}$ & 207 & 207 & 5,403 & 5,403 & & \\
\hline \multicolumn{7}{|c|}{ Panel B: Insider purchase transactions } \\
\hline$B H A R_{j t}$ & 0.063 & 0.031 & 0.020 & 0.009 & $-4.01++$ & $3.60++$ \\
\hline$M O M E N T U M_{j t}$ & 0.092 & 0.072 & 0.026 & 0.007 & $-2.64++$ & $2.48+$ \\
\hline$C R I M E_{i}$ & 0.480 & 0.000 & 0.338 & 0.000 & $-4.84++$ & $4.83++$ \\
\hline$A G E_{i}$ & 56.000 & 57.000 & 53.000 & 53.000 & $-4.70++$ & 4.34++ \\
\hline$G E N D E R_{i}$ & 0.923 & 1.000 & 0.903 & 1.000 & -1.19 & 1.08 \\
\hline$T_{E N U R E_{i j t}}$ & 1,001 & 833 & 1,481 & 1,032 & $7.81++$ & $-5.10++$ \\
\hline$C E O_{i j t}$ & 0.199 & 0.000 & 0.124 & 0.000 & $-3.08++$ & 3.70++ \\
\hline$B O A R D M E M_{i j t}$ & 0.472 & 0.000 & 0.519 & 1.000 & 1.53 & -1.53 \\
\hline$T R A D E V A L_{i j t}$ & 690 & 126 & 1,944 & 152 & $7.37++$ & $-3.05++$ \\
\hline VALUEDIV $V_{i j t}$ & 0.123 & 0.040 & 0.137 & 0.013 & 1.11 & $3.15++$ \\
\hline LIQUIDITY $_{i t}$ & -488 & -63 & -269 & -45 & 0.79 & $-1.70 *$ \\
\hline$D E C L O S S_{j t}$ & 0.044 & 0.000 & 0.057 & 0.000 & 0.96 & -0.86 \\
\hline$N U M I N S_{i t}$ & 0.996 & 1.000 & 1.245 & 1.000 & $5.23++$ & 0.69 \\
\hline $\mathrm{N}$ & 271 & 271 & 8,825 & 8,825 & & \\
\hline
\end{tabular}


Notes:

1. The table reports the results of the univariate analyses of insider trades and tax noncompliance behavior based on the 5,610 insider sale transactions (Panel A) and 9,096 purchase transactions (Panel B) in the sample. The sample includes all 3,392 insiders in all 394 listed firms in Sweden with at least one insider transaction over the period 2000-2008. Insider transactions are classified in two subgroups, namely transactions that have been made by insiders who have been charged with administrative penalties by the Skatteverket due to noncompliance with the tax law (Taxation Act 1990:324) in the year preceding insider transactions (noncompliant insiders), and transactions that have been made by insiders who have complied with the tax law in the year preceding insider transactions (compliant insiders). We use the t-test (Wilcoxon rank-sum test) to test whether the means (medians) of the variables are different between insider trades by noncompliant and those by compliant insiders.

2. All variable definitions can be found in Appendix 2. All continuous variables are Winsorized to the $1^{\text {st }}$ and $99^{\text {th }}$ percentiles of their distributions. The variables TRADEVAL $L_{i j t}$ and LIQUIDITY ${ }_{i t}$ are in thousands of SEK. 1 SEK is equal to 0.12 USD.

3. $*,+$, and ++ denote a statistically significant difference at the $0.10,0.05$, and 0.01 (two-tailed) level, respectively. 


\section{Table 6}

\section{Regression analysis of insiders' trading behavior and tax noncompliance behavior}

\begin{tabular}{|c|c|c|c|c|c|c|c|c|}
\hline \multirow[b]{2}{*}{ Variable } & \multicolumn{4}{|c|}{ Panel A: Insider sales } & \multicolumn{4}{|c|}{ Panel B: Insider purchases } \\
\hline & $\begin{array}{l}\text { Exp. } \\
\text { Sign }\end{array}$ & (1) & (2) & (3) & $\begin{array}{l}\text { Exp. } \\
\text { Sign }\end{array}$ & (4) & (5) & (6) \\
\hline$T A X_{i t}$ & - & $\begin{array}{l}-0.004 \\
(-2.80)++\end{array}$ & $\begin{array}{l}-0.004 \\
(-2.84)++\end{array}$ & $\begin{array}{c}-0.003 \\
(-2.21)+\end{array}$ & + & $\begin{array}{c}0.006 \\
(2.21)+\end{array}$ & $\begin{array}{c}0.005 \\
(2.01)+\end{array}$ & $\begin{array}{l}0.003 \\
(1.53)\end{array}$ \\
\hline$C R I M E_{i}$ & - & $\begin{array}{c}0.001 \\
(0.13)\end{array}$ & $\begin{array}{c}0.001 \\
(0.19)\end{array}$ & $\begin{array}{c}0.004 \\
(0.51)\end{array}$ & + & $\begin{array}{l}-0.000 \\
(-0.06)\end{array}$ & $\begin{array}{c}-0.001 \\
(-0.27)\end{array}$ & $\begin{array}{c}0.002 \\
(0.44)\end{array}$ \\
\hline$A G E_{i}$ & - & $\begin{array}{l}-0.002 \\
(-0.09)\end{array}$ & $\begin{array}{c}0.001 \\
(0.04)\end{array}$ & $\begin{array}{c}-0.021 \\
(-1.29)\end{array}$ & + & $\begin{array}{c}0.010 \\
(0.89)\end{array}$ & $\begin{array}{c}0.009 \\
(0.74)\end{array}$ & $\begin{array}{l}-0.002 \\
(-0.25)\end{array}$ \\
\hline$G E N D E R_{i}$ & - & $\begin{array}{c}0.009 \\
(1.18)\end{array}$ & $\begin{array}{c}0.010 \\
(1.29)\end{array}$ & $\begin{array}{r}0.005 \\
(0.61)\end{array}$ & + & $\begin{array}{c}0.005 \\
(0.96)\end{array}$ & $\begin{array}{c}0.001 \\
(0.17)\end{array}$ & $\begin{array}{c}-0.003 \\
(-0.71)\end{array}$ \\
\hline$T E N U R E_{i j t}$ & + & $\begin{array}{c}0.005 \\
(1.46)\end{array}$ & $\begin{array}{c}0.004 \\
(1.11)\end{array}$ & $\begin{array}{c}-0.001 \\
(-0.29)\end{array}$ & - & $\begin{array}{c}0.001 \\
(0.72)\end{array}$ & $\begin{array}{c}0.003 \\
(1.66)\end{array}$ & $\begin{array}{c}0.001 \\
(0.65)\end{array}$ \\
\hline$C E O_{i j t}$ & - & $\begin{array}{l}-0.025 \\
(-2.81)++\end{array}$ & $\begin{array}{l}-0.026 \\
(-2.90)++\end{array}$ & $\begin{array}{c}-0.019 \\
(-2.42)+\end{array}$ & + & $\begin{array}{c}0.004 \\
(0.61)\end{array}$ & $\begin{array}{c}0.002 \\
(0.26)\end{array}$ & $\begin{array}{c}-0.004 \\
(-0.61)\end{array}$ \\
\hline$B O A R D M E M_{i j t}$ & - & $\begin{array}{c}0.001 \\
(0.13)\end{array}$ & $\begin{array}{c}0.002 \\
(0.33)\end{array}$ & $\begin{array}{r}0.009 \\
(1.28)\end{array}$ & + & $\begin{array}{c}0.002 \\
(0.48)\end{array}$ & $\begin{array}{l}-0.003 \\
(-0.68)\end{array}$ & $\begin{array}{c}-0.003 \\
(-0.74)\end{array}$ \\
\hline$T R A D E V A L_{i j t}$ & + & $\begin{array}{c}0.003 \\
(2.00)+\end{array}$ & $\begin{array}{c}0.003 \\
(1.86)^{*}\end{array}$ & $\begin{array}{c}0.003 \\
(1.82) *\end{array}$ & - & $\begin{array}{l}-0.002 \\
(-1.59)\end{array}$ & $\begin{array}{l}-0.000 \\
(-0.53)\end{array}$ & $\begin{array}{c}-0.001 \\
(-0.67)\end{array}$ \\
\hline VALUEDIV & - & $\begin{array}{c}-0.007 \\
(-0.75)\end{array}$ & $\begin{array}{l}-0.004 \\
(-0.49)\end{array}$ & $\begin{array}{c}-0.001 \\
(-0.14)\end{array}$ & + & $\begin{array}{c}0.004 \\
(0.49)\end{array}$ & $\begin{array}{c}0.000 \\
(0.04)\end{array}$ & $\begin{array}{c}-0.000 \\
(-0.03)\end{array}$ \\
\hline$L_{L U U I D T Y}{ }_{i t}$ & - & $\begin{array}{c}-0.001 \\
(-1.69) *\end{array}$ & $\begin{array}{c}-0.001 \\
(-1.73)^{*}\end{array}$ & $\begin{array}{c}-0.001 \\
(-2.26)+\end{array}$ & + & $\begin{array}{c}0.000 \\
(1.25)\end{array}$ & $\begin{array}{c}0.000 \\
(1.50)\end{array}$ & $\begin{array}{c}0.000 \\
(1.60)\end{array}$ \\
\hline$D E C L O S S_{j t}$ & + & $\begin{array}{c}0.091 \\
(5.78)++\end{array}$ & $\begin{array}{c}0.090 \\
(5.47)++\end{array}$ & $\begin{array}{c}0.088 \\
(5.34)++\end{array}$ & + & $\begin{array}{c}0.067 \\
(6.47)++\end{array}$ & $\begin{array}{c}0.063 \\
(6.27)++\end{array}$ & $\begin{array}{l}0.065 \\
(6.36)++\end{array}$ \\
\hline$N U M I N S_{i t}$ & - & $\begin{array}{l}-0.004 \\
(-0.65)\end{array}$ & $\begin{array}{l}-0.005 \\
(-0.84)\end{array}$ & $\begin{array}{l}-0.017 \\
(-2.55)+\end{array}$ & + & $\begin{array}{l}-0.001 \\
(-0.32)\end{array}$ & $\begin{array}{c}0.001 \\
(0.42)\end{array}$ & $\begin{array}{c}0.000 \\
(0.07)\end{array}$ \\
\hline MOMENTUM $M_{j t}$ & - & & $\begin{array}{c}-0.005 \\
(-0.58)\end{array}$ & $\begin{array}{l}-0.027 \\
(-3.70)++\end{array}$ & - & & $\begin{array}{l}-0.007 \\
(-0.86)\end{array}$ & $\begin{array}{l}-0.025 \\
(-2.83)++\end{array}$ \\
\hline$R O A_{j t}$ & + & & $\begin{array}{c}0.010 \\
(0.53)\end{array}$ & $\begin{array}{c}0.002 \\
(0.07)\end{array}$ & + & & $\begin{array}{c}0.002 \\
(0.16)\end{array}$ & $\begin{array}{l}-0.018 \\
(-1.11)\end{array}$ \\
\hline$L N M V_{j t}$ & + & & $\begin{array}{c}0.000 \\
(0.22)\end{array}$ & $\begin{array}{l}-0.032 \\
(-4.16)++\end{array}$ & - & & $\begin{array}{l}-0.005 \\
(-4.41)++\end{array}$ & $\begin{array}{l}-0.016 \\
(-2.20)+\end{array}$ \\
\hline$P B_{j t}$ & - & & $\begin{array}{l}-0.001 \\
(-0.75)\end{array}$ & $\begin{array}{c}0.002 \\
(1.23)\end{array}$ & - & & $\begin{array}{l}-0.000 \\
(-0.51)\end{array}$ & $\begin{array}{c}0.001 \\
(0.34)\end{array}$ \\
\hline INTERCEPT & & $\begin{array}{c}-0.051 \\
(-0.59)\end{array}$ & $\begin{array}{l}-0.052 \\
(-0.58)\end{array}$ & $\begin{array}{c}-0.069 \\
(-0.80)\end{array}$ & & $\begin{array}{c}-0.030 \\
(-0.58)\end{array}$ & $\begin{array}{l}-0.035 \\
(-0.66)\end{array}$ & $\begin{array}{l}-0.024 \\
(-0.50)\end{array}$ \\
\hline $\begin{array}{l}\text { Firm fixed } \\
\text { effects }\end{array}$ & & No & No & Yes & & No & No & Yes \\
\hline
\end{tabular}




\begin{tabular}{|c|c|c|c|c|c|c|}
\hline $\begin{array}{l}\text { Year fixed } \\
\text { effects }\end{array}$ & Yes & Yes & Yes & Yes & Yes & Yes \\
\hline Adj. $R^{2}$ & 0.039 & 0.044 & 0.185 & 0.031 & 0.035 & 0.120 \\
\hline N obs & 5,610 & 5,610 & 5,610 & 9,096 & 9,096 & 9,096 \\
\hline
\end{tabular}

Notes:

1. The table reports the results of estimating Model (1) from the sample of 5,610 insider sale transactions (Panel A) and 9,096 insider purchase transactions (Panel B), respectively, to test whether insiders who have shown noncompliance with the tax law (noncompliant insiders) use more of their information advantage when trading their insider stocks, relative to other insiders (compliant insiders). The sample includes all 3,392 insiders in all 394 listed firms in Sweden with at least one insider transaction over the period 2000-2008.

2. Model (1) is as follows:

$$
\begin{aligned}
\text { BHAR }_{j t}= & \alpha_{0}+\beta_{1} \text { TAX }_{i t}+\beta_{2} \text { CRIME }_{i}+\beta_{3} A G E_{i}+\beta_{4} \text { GENDER }_{i}+\beta_{5} \text { TENURE }_{i j t}+\beta_{6} \text { CEO }_{i j t} \\
& +\beta_{7} \text { BOARDMEM }_{i j t}+\beta_{8} \text { TRADEVAL }_{i j t}+\beta_{9} \text { VALUEDIV V }_{i j t}+\beta_{10} \text { LIQUIDITY }_{i t} \\
& +\beta_{11} \text { DECLOSS }_{j t}+\beta_{12} \text { NUMINS }_{i t}+\beta_{13} \text { MOMENTUM }_{j t}+\beta_{14} \text { ROA }_{j t}+\beta_{15} L N M V_{j t} \\
& +\beta_{16} \text { PB }_{j t}+\sum_{k=1}^{394} \varphi_{k} \text { FIRM }_{k_{j}}+\sum_{y=2000}^{2007} \gamma_{y} \text { YEAR }_{y}+\varepsilon_{i j t}
\end{aligned}
$$

3. The dependent variable is the market-adjusted buy-and-hold return over the one-month period following the day on which an insider sells her insider stock $j\left(B H A R_{j t}\right)$. The variable $T A X_{i t}$ is equal to the SEK value of total administrative penalties assessed by the Skatteverket on insider $i$ due to noncompliance with the tax law (Taxation Act 1990:324) in the year preceding day $t$, and zero otherwise. All other variables are defined as in Appendix 2. All continuous variables are Winsorized to the $1^{\text {st }}$ and $99^{\text {th }}$ percentiles of their distributions.

4. Regression analyses use the natural logarithm of $\left(1+T A X_{i t}\right),\left(1+T E N U R E_{i j t}\right), T R A D E V A L_{i j t}$, $\left(1+\right.$ LIQUIDITY $\left._{i t}\right)$, and $\left(1+N U M I N S_{i t}\right)$.

5. Firm and year fixed effects are included but are not reported for the sake of brevity. The $t$-statistics appear in parentheses and are based on standard errors adjusted for heteroskedasticity and clustered by firm.

6. $*,+$, and ++ denote statistical significance at the $0.10,0.05$, and 0.01 (two-tailed) level, respectively. 


\section{Table 7}

\section{Regression analysis of insiders' trading behavior and tax noncompliance behavior: Reduced sample}

\begin{tabular}{|c|c|c|c|c|c|c|c|c|}
\hline \multirow[b]{2}{*}{ Variable } & \multicolumn{4}{|c|}{ Panel A: Insider sales } & \multicolumn{4}{|c|}{ Panel B: Insider purchases } \\
\hline & $\begin{array}{l}\text { Exp. } \\
\text { Sign }\end{array}$ & (1) & (2) & (3) & $\begin{array}{l}\text { Exp. } \\
\text { Sign }\end{array}$ & (4) & $(5)$ & (6) \\
\hline$T A X_{i t}$ & - & $\begin{array}{c}-0.004 \\
(-1.92)^{*}\end{array}$ & $\begin{array}{c}-0.004 \\
(-2.01)+\end{array}$ & $\begin{array}{c}-0.004 \\
(-1.92) *\end{array}$ & + & $\begin{array}{c}0.009 \\
(4.63)++\end{array}$ & $\begin{array}{c}0.008 \\
(4.56)++\end{array}$ & $\begin{array}{c}0.006 \\
(3.22)++\end{array}$ \\
\hline$C R I M E_{i}$ & - & $\begin{array}{c}0.001 \\
(0.11)\end{array}$ & $\begin{array}{c}0.001 \\
(0.18)\end{array}$ & $\begin{array}{c}0.003 \\
(0.47)\end{array}$ & + & $\begin{array}{c}0.002 \\
(0.47)\end{array}$ & $\begin{array}{c}0.001 \\
(0.26)\end{array}$ & $\begin{array}{c}0.004 \\
(0.82)\end{array}$ \\
\hline$A G E_{i}$ & - & $\begin{array}{l}-0.002 \\
(-0.12)\end{array}$ & $\begin{array}{c}0.000 \\
(0.02)\end{array}$ & $\begin{array}{c}-0.02 \\
(-1.31)\end{array}$ & + & $\begin{array}{c}0.012 \\
(1.07)\end{array}$ & $\begin{array}{c}0.011 \\
(0.92)\end{array}$ & $\begin{array}{c}-0.001 \\
(-0.06)\end{array}$ \\
\hline$G E N D E R_{i}$ & - & $\begin{array}{c}0.009 \\
(1.19)\end{array}$ & $\begin{array}{c}0.010 \\
(1.29)\end{array}$ & $\begin{array}{c}0.004 \\
(0.56)\end{array}$ & + & $\begin{array}{c}0.005 \\
(1.00)\end{array}$ & $\begin{array}{c}0.001 \\
(0.15)\end{array}$ & $\begin{array}{c}-0.003 \\
(-0.61)\end{array}$ \\
\hline$T E N U R E_{i j t}$ & + & $\begin{array}{c}0.005 \\
(1.37)\end{array}$ & $\begin{array}{c}0.004 \\
(1.06)\end{array}$ & $\begin{array}{c}-0.001 \\
(-0.25)\end{array}$ & - & $\begin{array}{c}0.001 \\
(0.36)\end{array}$ & $\begin{array}{c}0.002 \\
(1.38)\end{array}$ & $\begin{array}{r}0.001 \\
(0.54)\end{array}$ \\
\hline$C E O_{i j t}$ & - & $\begin{array}{l}-0.027 \\
(-2.96)++\end{array}$ & $\begin{array}{l}-0.028 \\
(-3.07)++\end{array}$ & $\begin{array}{c}-0.020 \\
(-2.43)+\end{array}$ & + & $\begin{array}{c}0.005 \\
(0.82)\end{array}$ & $\begin{array}{c}0.003 \\
(0.47)\end{array}$ & $\begin{array}{c}-0.003 \\
(-0.56)\end{array}$ \\
\hline BOARDMEM $M_{i j t}$ & - & $\begin{array}{c}0.001 \\
(0.16)\end{array}$ & $\begin{array}{c}0.002 \\
(0.34)\end{array}$ & $\begin{array}{r}0.009 \\
(1.30)\end{array}$ & + & $\begin{array}{c}0.003 \\
(0.62)\end{array}$ & $\begin{array}{c}-0.003 \\
(-0.62)\end{array}$ & $\begin{array}{c}-0.003 \\
(-0.70)\end{array}$ \\
\hline$T R A D E V A L_{i j t}$ & + & $\begin{array}{c}0.003 \\
(1.79)^{*}\end{array}$ & $\begin{array}{c}0.003 \\
(1.73)^{*}\end{array}$ & $\begin{array}{c}0.003 \\
(1.68)^{*}\end{array}$ & - & $\begin{array}{c}-0.002 \\
(-1.55)\end{array}$ & $\begin{array}{c}-0.000 \\
(-0.42)\end{array}$ & $\begin{array}{c}-0.001 \\
(-0.93)\end{array}$ \\
\hline$V A L U E D I V_{i j t}$ & - & $\begin{array}{c}-0.006 \\
(-0.63)\end{array}$ & $\begin{array}{l}-0.003 \\
(-0.37)\end{array}$ & $\begin{array}{l}-0.000 \\
(-0.03)\end{array}$ & + & $\begin{array}{r}0.006 \\
(0.75)\end{array}$ & $\begin{array}{r}0.002 \\
(0.30)\end{array}$ & $\begin{array}{c}0.001 \\
(0.16)\end{array}$ \\
\hline LIQUIDITY $_{i t}$ & - & $\begin{array}{c}-0.001 \\
(-1.62)\end{array}$ & $\begin{array}{c}-0.001 \\
(-1.66) *\end{array}$ & $\begin{array}{c}-0.000 \\
(-2.06)+\end{array}$ & + & $\begin{array}{c}0.000 \\
(1.70)^{*}\end{array}$ & $\begin{array}{c}0.000 \\
(1.97)+\end{array}$ & $\begin{array}{c}0.000 \\
(2.02)+\end{array}$ \\
\hline$D E C L O S S_{j t}$ & + & $\begin{array}{c}0.091 \\
(5.67)++\end{array}$ & $\begin{array}{c}0.090 \\
(5.38)++\end{array}$ & $\begin{array}{c}0.088 \\
(5.12)++\end{array}$ & + & $\begin{array}{l}0.067 \\
(6.44)++\end{array}$ & $\begin{array}{l}0.062 \\
(6.24)++\end{array}$ & $\begin{array}{c}0.066 \\
(6.43)++\end{array}$ \\
\hline$N U M I N S_{i t}$ & - & $\begin{array}{l}-0.003 \\
(-0.52)\end{array}$ & $\begin{array}{l}-0.004 \\
(-0.69)\end{array}$ & $\begin{array}{c}-0.018 \\
(-2.49)+\end{array}$ & + & $\begin{array}{l}-0.002 \\
(-0.60)\end{array}$ & $\begin{array}{c}0.001 \\
(0.22)\end{array}$ & $\begin{array}{l}-0.000 \\
(-0.12)\end{array}$ \\
\hline$M O M E N T U M_{j t}$ & - & & $\begin{array}{c}-0.005 \\
(-0.56)\end{array}$ & $\begin{array}{l}-0.028 \\
(-3.66)++\end{array}$ & - & & $\begin{array}{c}-0.007 \\
(-0.84)\end{array}$ & $\begin{array}{l}-0.022 \\
(-2.58)++\end{array}$ \\
\hline$R O A_{j t}$ & + & & $\begin{array}{c}0.008 \\
(0.41)\end{array}$ & $\begin{array}{c}-0.007 \\
(-0.19)\end{array}$ & + & & $\begin{array}{l}-0.002 \\
(-0.12)\end{array}$ & $\begin{array}{c}-0.023 \\
(-1.37)\end{array}$ \\
\hline$L N M V_{j t}$ & + & & $\begin{array}{c}0.000 \\
(0.23)\end{array}$ & $\begin{array}{l}-0.031 \\
(-3.99)++\end{array}$ & - & & $\begin{array}{l}-0.005 \\
(-4.67)++\end{array}$ & $\begin{array}{c}-0.016 \\
(-2.17)+\end{array}$ \\
\hline$P B_{j t}$ & - & & $\begin{array}{l}-0.001 \\
(-0.75)\end{array}$ & $\begin{array}{c}0.002 \\
(1.27)\end{array}$ & - & & $\begin{array}{l}-0.000 \\
(-0.66)\end{array}$ & $\begin{array}{c}0.001 \\
(0.36)\end{array}$ \\
\hline INTERCEPT & & $\begin{array}{l}-0.046 \\
(-0.52)\end{array}$ & $\begin{array}{l}-0.049 \\
(-0.54)\end{array}$ & $\begin{array}{c}-0.063 \\
(-0.74)\end{array}$ & & $\begin{array}{c}-0.036 \\
(-0.69)\end{array}$ & $\begin{array}{l}-0.042 \\
(-0.79)\end{array}$ & $\begin{array}{c}-0.029 \\
(-0.59)\end{array}$ \\
\hline $\begin{array}{l}\text { Firm fixed } \\
\text { effects }\end{array}$ & & No & No & Yes & & No & No & Yes \\
\hline
\end{tabular}




\begin{tabular}{lrrrrrr}
\hline $\begin{array}{l}\text { Year fixed } \\
\text { effects }\end{array}$ & Yes & Yes & Yes & Yes & Yes & Yes \\
Adj.R & & & & & & \\
N obs & 0.037 & 0.038 & 0.185 & 0.031 & 0.038 & 0.120 \\
\hline
\end{tabular}

Notes:

1. The table reports the results of estimating Model (1) from the sample of 5,473 insider sale transactions (Panel A) and 8,966 insider purchase transactions (Panel B) from the reduced sample that includes only those noncompliant insiders who have not been convicted or suspected of crimes.

2. Model (1) is as follows:

$$
\begin{aligned}
\text { BHAR }_{j t}= & \alpha_{0}+\beta_{1} \text { TAX }_{i t}+\beta_{2} \text { CRIME }_{i}+\beta_{3} A G E_{i}+\beta_{4} \text { GENDER }_{i}+\beta_{5} \text { TENURE }_{i j t}+\beta_{6} \text { CEO }_{i j t} \\
& +\beta_{7} \text { BOARDMEM }_{i j t}+\beta_{8} \text { TRADEVAL }_{i j t}+\beta_{9} \text { VALUEDIV V }_{i j t}+\beta_{10} \text { LIQUIDITY }_{i t} \\
& +\beta_{11} \text { DECLOSS }_{j t}+\beta_{12} \text { NUMINS }_{i t}+\beta_{13} \text { MOMENTUM }_{j t}+\beta_{14} \text { ROA }_{j t}+\beta_{15} \text { LNMV }_{j t} \\
& +\beta_{16} P_{j t}+\sum_{k=1}^{394} \varphi_{k} \text { FIRM }_{k_{j}}+\sum_{y=2000}^{2007} \gamma_{y} Y_{y} \text { IR }_{y}+\varepsilon_{i j t}
\end{aligned}
$$

3. The dependent variable is the market-adjusted buy-and-hold return over the one-month period following the day on which an insider sells her insider stock $j\left(B H A R_{j t}\right)$. The variable $T A X_{i t}$ is equal to the SEK value of total administrative penalties assessed by the Skatteverket on insider $i$ due to noncompliance with the tax law (Taxation Act 1990:324) in the year preceding day $t$, and zero otherwise. All other variables are defined as in Appendix 2. All continuous variables are Winsorized to the $1^{\text {st }}$ and $99^{\text {th }}$ percentiles of their distributions.

4. Regression analyses use the natural logarithm of $\left(1+T A X_{i t}\right),\left(1+T E N U R E_{i j t}\right), T R A D E V A L_{i j t}$, $\left(1+\right.$ LIQUIDITY $\left._{i t}\right)$, and $\left(1+N U M I N S_{i t}\right)$.

5. Firm and year fixed effects are included but are not reported for the sake of brevity. The $t$-statistics appear in parentheses and are based on standard errors adjusted for heteroskedasticity and clustered by firm.

6. * $*$, and ++ denote statistical significance at the $0.10,0.05$, and 0.01 (two-tailed) level, respectively. 